\title{
AN INTEGRATED PERSPECTIVE ON THE AUSTRONESIAN DIASPORA: The Switch from Cereal Agriculture to Maritime Foraging in the Colonisation of Island Southeast Asia
}

\author{
David Bulbeck
}

\begin{abstract}
This paper reviews the archaeological evidence for maritime interaction spheres in Island Southeast Asia during the Neolithic and preceding millennia. It accepts that cereal agriculture was well-established in Taiwan during the Neolithic but finds minimal evidence for the transmission of agriculture from Taiwan to Island Southeast Asia. Accordingly, the scholarly dispute in early Austronesian culture history between farming and maritime perspectives is deemed to be based on a vacuous opposition. In terms of a foraging/ farming dichotomy, Austronesians' origins were evidently associated with cereal agriculture in the region of the Taiwan Strait, but their southward expansion was predicated on maritime foraging and trade.
\end{abstract}

\section{Introduction}

One of the interests Sandra Bowdler pursued, during the time I was a colleague at the University of Western Australia, was the persistence of the hunter-gatherer economy in the Kimberleys and Arnhem Land despite centuries of visitation by Macassan sea-cucumber collectors. Even though some Aborigines toured Macassar, and witnessed first-hand its agriculturally-based subsistence economy, there was not the slightest tendency for the northern Australian Aboriginal economy to incorporate agricultural practices (Bowdler 2002). My interest looks at this same interaction from an Island Southeast Asian (ISEA) point of view: Why did these visiting Macassans not make some sort of agricultural incursion into northern Australia? Why did they restrict their economic activities in Australia to trade? I see here an ethnohistorical allegory that could clarify poorly-understood aspects of the Austronesian diaspora.

Austronesians are defined as people whose first language belongs to the Austronesian family. Most historical linguists assign all the ex-Taiwan Austronesian languages, from Madagascar through ISEA and the Pacific, to a single 'MalayoPolynesian' branch, of essentially the same time-depth as the nine branches of Austronesian restricted to Taiwan (Pawley 2002). The hypothetical, reconstructed ancestor of these indistinguishably deep branches, both ex-Taiwan (descended from proto-MalayoPolynesian, or PMP) and in Taiwan, is referred to as ProtoAustronesian (PAN). PAN itself would have had an ancestor, which may bc labelled pre-Austronesian, distinguishable from PAN by dint of the implausibility of its reconstruction from extant Austronesian languages through standard historical linguistic techniques. While numerous proposals have been published for a decp-seated relationship between Austronesian

School of Archaeology and Anthropology, Australian Nationa University, Canberra, ACT 0200, Australia David.Bulbeck@anu.edu.au and the language families of adjacent mainland Asia (AustroAsiatic, Tai-Kadai, Sino-Tibetan), linguists have been unable to agree on the exact nature of any such relationship (Sagart 2005; Sagart et al. 2005).

Howells (1973) and Shutler and Marck (1975) were early proponents for an agriculturally-driven dispersal of Austronesians from a PAN homeland in Taiwan, linked to still earlier food production developments in southern China. In the 1970s and 1980s, archaeologists accepted a mid-Holocene dating for the spread of pottery across Southeast Asia and Taiwan, and its association with the expansion of early, settled agricultural populations, as supported by Pawley and Green's (1973) and Blust's (1976) reconstruction of agricultural terms in the PAN lexicon (see Bellwood 1978, 1985). Subsequently, critical scrutiny of the dating evidence suggested a very rapid spread of Austronesians across ISEA after 4000 BP (Bellwood 1997; Spriggs 1989), but a Taiwan homeland, and agriculturallyfuelled mode of dispersal, have remained as tenets of what is still the orthodox theory on early Austronesian culture history (Pawley 2002). Indeed, recent archaeological research in Taiwan has documented numerous settlements, with cereal agriculture (including millet, another PAN reconstruction), by the fifth millennium BP (Bellwood 2005a; Tsang 2007).

Against this view, W.G. Solheim II has championed a maritime theory on Austronesian origins. He coined the term 'Nusantao' for a sailing people who, according to Solheim, had expanded across a wide swathe of the Pacific and tropical to temperate East Asia. Initially he identified them with the original Austronesians, and located their nursery in southeastern ISEA (Solheim 1975, 1984-1985). Currently, Solheim (2006) proposes that the Nusantao, being the linguistic ancestors of Austro-Asiatic and Thai-Kadai as well as Austronesian, arose on the coast of central Vietnam in the terminal Pleistocene. He identifies southeastern ISEA as the pre-Austronesian homeland, and further recognises a PAN homeland that had connected central Victnam, northern Bornco, Palawan and Luzon across the South China Sea.

Meacham has developed a similar position to Solheim's. He argues that the Austronesian homeland covered a vast area, the triangle from Taiwan in the north to Sumatra in the southwest and Nusatenggara in the southeast. The Taiwan branches of PAN are deeply-rooted because Taiwan was the first component to become isolated from the remainder of the maritime network; south of Taiwan, PAN only later split into its Western MalayoPolynesian, Central Malayo-Polynesian and Oceanic branches (Meacham 1984-1985, 2004). Oppenheimer (1998) provided this view with a basis in palaeogeography by proposing that the drowning of Sundaland at the Pleistocene-Holocene junction spurred the maritime expansion of early Austronesians across the ISEA region. Recently, the analysis of large samples of human 
mitochondrial DNA (mtDNA) from ISEA, Taiwan and adjacent regions has provided strong support for population dispersals associated with late Quaternary sea-level rises, in addition to support for some level of emigration from Taiwan into ISEA following the mid-Holocene (Hill et al. 2007; Soares et al. 2008).

This paper reviews the archaeological evidence for identifying the ISEA Neolithic with the expansion of agricultural populations southward from Taiwan or with the continuation of an indigenous ISEA tradition of maritime sailing. I reserve the term Neolithic for assemblages with pottery or polished stone tools which pre-date c. $2500 \mathrm{BP}$, after which time the dispersal of iron and bronze across ISEA ushered in the region's Early Metal Phase (Bellwood 1997:268; Hung et al. 2007). The tendency of some writers to equate the Neolithic with early agriculture (e.g. Bellwood 2005a; Matsumura and Hudson 2005) blatantly assumes what should be a matter of investigation: the specificity of an association between ISEA Neolithic assemblages and agricultural subsistence practices.

In this paper, archaeological materials will receive a late dating' by default unless there is reasonable physical evidence for a greater antiquity. For instance, notwithstanding the common occurrence of potsherds in ISEA Neolithic deposits, pottery production continued to increase in ISEA during the Metal Phase (e.g. Bellwood 1998; Soegondho 1995), and this should be the default dating for otherwise undated pottery. Further, as is now well-recognised (e.g. Bellwood 1997, 2000; Spriggs 2003, 2007), potsherds can infiltrate older deposits, accounting for the precocious determinations of 4500-6000 BP for the deepest pottcry at rockshelters such as Ulu Leang 2 in Sulawesi, Bukit Tengkorak in Sabah and Lubang Payau in Kalimantan. In cases such as these, other Neolithic materials may also have worked their way downwards with the potsherds, but the charcoal used for dating is inferred to be in situ as it returned dates of apparently pre-ceramic antiquity. The conservative dating policy adopted here can be illustrated through application to the East Timor rockshelters excavated by Glover (1986). The distinction between Neolithic and post-Neolithic deposits is based on whether the pottery-bearing layer precedes or postdates $2500 \mathrm{BP}$ according to Glover's chronological estimates. The distinction between pre-Neolithic and Neolithic, on the other hand, depends on whether a layer older than 2500 BP has any potsherds; greater depth than any pottery is taken as physical evidence of the pre-Neolithic antiquity of all contained remains (Table 1). While conservative, my dating policy avoids the trap of 'creating' Neolithic assemblages based on the archaeologist's preconceptions, as can happen if rampant infiltration or faulty dating is invoked to propose a Neolithic association for selected finds regardless of the stratigraphic and radiometric evidence.

\section{Unique Status of Austronesian as a Neolithic Expansion}

Bellwood (2005a; Diamond and Bellwood 2003) attempts to include Austronesian under his general theory that the world's major language families were established through the expansion of early farmers. Austronesian, however, and the area where Austronesian languages are spoken, received limited attention in Bellwood's (2005a) First Farmers, which may reflect the fact that Austronesian is completely unlike the world's other widespread language families. Austronesian is unique on one hand by being the language of an island world, and on the other hand by experiencing an almost total replacement of its staple crops as part and parcel of its major expansion (Spriggs 2003, 2007). The general case with the language families detailed by Bellwood (2005a) involved an overland expansion from an agricultural heartland by farmers who, at the end of their Neolithic journey, were planting essentially the same crops as had been domesticated in the homeland. The Austronesians, by contrast, appear to have been 'terrestrially challenged', having achieved only marginal penetration of mainland Southeast Asia and New Guinea, while they also rapidly switched from grain cultivation to the root and arboreal crops which dominate Pacific agricultural systems. I would like to propose this was no coincidence; rather, colonisation of the Austronesians' island world was predicated on their ability to combine exploitation of maritime environments with the planting of locally-adapted crops which could be productively harvested with minimal tending.

How much agriculture fuelled the ISEA Austronesian expansion may have varied, but probably was generally slight. Consider the twin Neolithic hamlets of Kamassi and Minanga Sipakko in central Sulawesi, whose longevity of occupation has previously been ascribed to these sites' combination of boating access to the sea and up-valley, pedestrian access to highland forests, as well as local access to riverine resources and river flats (Bulbeck and Nasruddin 2002). Recent excavations at Minanga Sipakko demonstrate continuous Neolithic habitation for well over a millennium, but the identified plant remains are restricted to the candlenut, which need hardly have been cultivated, while the faunal remains include fish (marine and riverine), fowl, forest animals (both introduced and indigenous), and dog as the sole identified domesticate (Simanjuntak et al. 2008). Analysis of the Minanga Sipakko pollen suggests unchanged vegetation throughout the period of Neolithic habitation (Vita 2008), which implies minimal forest clearance for agriculture. If the assumption of agricultural demic diffusion during the Neolithic has any validity for ISEA, surely Minanga Sipakko would have produced evidence of field agriculture and deforestation, instead of remains which could be comfortably accommodated under the rubric of a foraging subsistence economy.

What of the Neolithic rice remains from Andarayan in northern Luzon, and Gua Sireh and Niah in Sarawak (Table 2)? Both of these areas are clearly important for understanding the ISEA Neolithic, particularly as a second shared distinction is acceptable evidence of pottery before $4000 \mathrm{BP}$ (see below). A third distinction, and this appears critical for correct interpretation of the evidence, is their proximity to areas where the Neolithic had been established well before 4000 years ago - respectively, Taiwan and Vietnam. If Andarayan and Gua Sireh/Niah represent expansion by Neolithic rice farmers, then on current evidence they would represent a failed expansion by rice farmers who had come thus far, and no farther. Indeed, overseas trade of rice to Sarawak and north Luzon from mainland Southeast Asia and Taiwan would not be beyond the bounds of possibility, given the evidence (to be reviewed) for mid-Holocene, long-distance maritime trade. If, however, we are dealing with Neolithic rice farmers in Sarawak and northern Luzon, this subsistence strategy would appear to have been entirely unsuitable for sustained Austronesian expansion, which instead was facilitated by a switch to a subsistence economy that did not tie community members to one spot. 
Table 1 Pre-Neolithic, Neolithic and post-Neolithic layers from Glover's (1986) East Timor rockshelters (see text). The distinction between postNeolithic and Neolithic layers is based on Glover's inferred chronology, but the distinction between Neolithic and pre-Neolithic layers is based on the inclusion of potsherds.

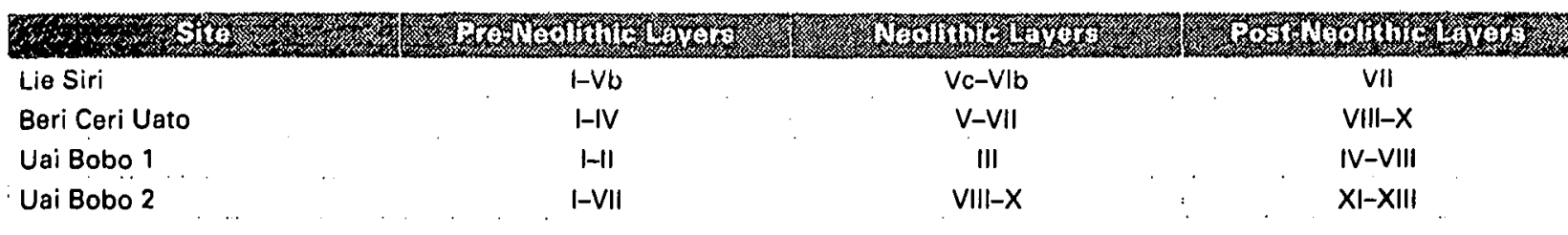

Table 2 Presences and counts (where available) of identified pre-Neolithic and Neolithic plant remains from Island Southeast Asia (excluding sedges). + a presence. +t = abundance. References: 1: Bellwood (1995, 1998); Paz (2004, 2005); Simenjuntak and Prasetyo (2002); van Heekeren (1972:146). 2: Glover (1986): Simanjuntak and Prasatyo (2002): Simanjuntak ot al (in press). 3. Glover (1986): O'Connor et al. (2005a, 2005b). 4: Mijares (2007:19, 53), 5: Paz (2004, 2005). 6: Paz (2005). 7: Paz (2005); Barker (2005); Bellwood (2005a); Mijares (2007). 8: Mijares (2007:49); Paz (2005). 9: Mijares (2007:49-52). 10: Mijares (2007:16. 51). 11: Paz (2004) (further remains from spits 1 and 2 in Leang Burung 1 Trench A probably postdate 1500 BP - cf. Paz 2005:1 13). 12: Glover (1986).

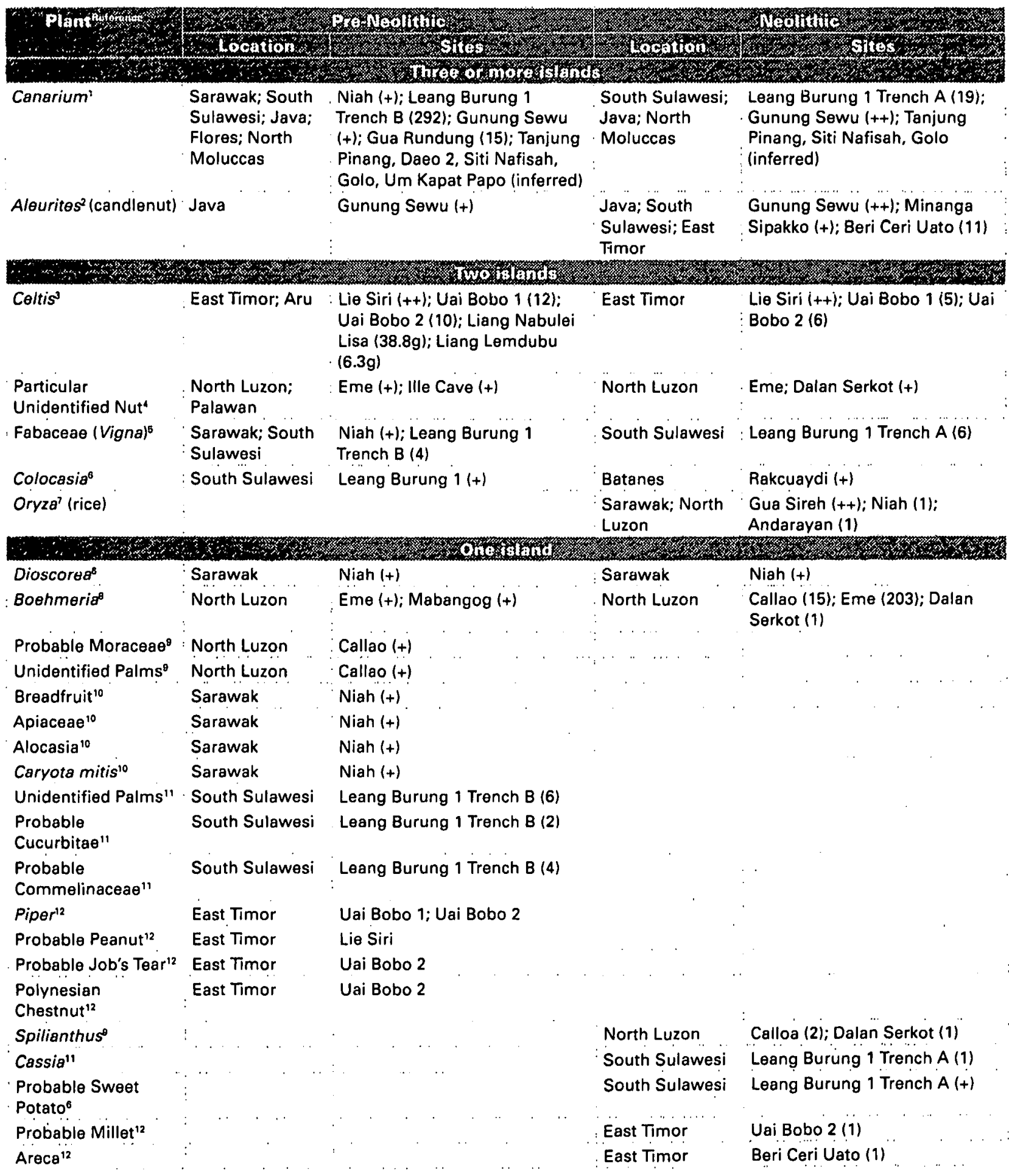


Bellwood (1997, 2005a), followed by $\mathrm{Paz}(2002,2005)$ and Mijares (2007), argues that the early Austronesians domesticated local tubers and arboreal crops during their migration through ISEA. Central to this argument is, apart from a grudging acceptance of desultory replanting of roots and fruits, the claimed lack of evidence for pre-Neolithic ISEA agriculture. However, the archaeological evidence for the exploitation of non-cereal plant resources appears to be stronger prior to the Neolithic than during the Neolithic (Table 2). Of the plants evidenced for both periods, the candlenut alone appears to have been more intensively and extensively exploited during the Neolithic. Wild ramie (Boehmeria) was evidently exploited more intensively during the Neolithic in North Luzon, but it has not been reported elscwhere, and this exploitation may reflect its use for fibres (Mijares 2007:54-59). Overall, a much greater variety of plant remains date to the pre-Neolithic than the Neolithic. Further, apart from the special case of rice, there are as many domesticates identified for the pre-Neolithic (peanut, Job's tear) as for the Neolithic (millet, sweet potato) (or should we reject the peanut and sweet potato identifications as too tendentious, given the origins of these plants in South America, evidence for ISEA agriculture would be diminished for the Neolithic as well as the pre-Neolithic). Even the old argument about non-cereal crop reconstructions in PMP (Blust 1995) has been turned on its head by Blench (2004) who shows that many of the trees planted in ISEA seem to have originated in the Moluccas or Melanesia, before being introduced to ISEA prior to the region's colonisation by Austronesians (see also Spriggs 2007).

The archaeological cvidence for faunal transport also mitigates against a scenario of a Taiwan-based incursion of farmers into ISEA. Niah Cave provides us with the northernmost instance of early faunal introduction (dogs, domestic pigs), and even here the remains could be post-Neolithic (Barker 2005:101). Otherwise, all the recorded faunal introductions were to Wallacean islands south of the Philippines. The earliest introductions involved the westward transport of marsupials from New Guinea, succeeded by traffic in potential domesticates - the Celebes boar to Flores, and perhaps Capra/Ovis to Timor (Table 3). Sus celebensis so dominates the pre-ceramic Holocene faunal remains from the Maros sites in South Sulawesi that it was minimally a commensal and conceivably a domesticate (Simons and Bulbeck 2004). Perhaps this was also the species of pig introduced during the Neolithic to Timor (Spriggs 2003:65) and the Moluccas (Bellwood 1997:230). The problematic early/ mid-Holocene Capra/Ovis remains in East Timor can hardly be attributed to contamination from the Neolithic layers, which yielded a smaller tally of specimens (Table 4). The specifically Neolithic introductions (Table 3) include wild Eurasian mammals (porcupine, monkey, perhaps the Timor deer) as well as domesticates (cattle/water buffalo, dog, Sus scrofa). In summary, the major motivation for faunal transport appears to have been to supplement the depauperate fauna of eastern Indonesia (cf. Bellwood 1997:231), and the evidence is mixed, at best, for a Neolithic switch from wild to domesticated animals.

If we follow Bellwood's (2005a:25-28) one-zero view on agriculture, whereby socicties are either caught on the agricultural treadmill or engage in nil to minimal agriculture, then, based on the current archaeological evidence, the Austronesian Neolithic across most of ISEA must be classified as the latter. My designation of the early Austronesian economy in ISEA as a fundamentally foraging economy should not appear too adventurous, given Higham's (2002) similar characterisation of the Da But, Bau Tro and Khok Phanom Di sites, with their rich Neolithic material culture spanning the general period 3500-6500 BP.

\section{Methodology for Investigating ISEA Maritime} Networks

To address the previously raised issues, this study investigates the evidence for interisland exchange and maritime interaction spheres in prehistoric ISEA and adjacent regions. Pottery and domesticates are included but not privileged in the analysis - any archaeological trait will suffice. This is to avoid the circular argument of accepting for analysis only that evidence which would lead to the conclusion of an agriculturally-fuelled, demic diffusion, signalled by the arrival of pottery as the key indicator.

Acceptable evidence for maritime interaction is based on three criteria. The first criterion has been alluded to in the discussion of faunal transport; when a well-sourced item has crossed the sea beyond its natural range, cultural exchange is indicated even in the absence of supporting archaeological evidence for the item's exploitation at its source.

The second criterion is to infer evidence for social interaction based on shared, contemporary rarities in the archaeological record from sites within reasonable proximity to each other, even if separated by bodies of water. The rarer the trait, the more discrete the match and the closer the locations, the stronger the evidence. Celtis, whose seeds appear to be edible and whose bark can be used for cloth and has medicinal properties (Glover 1986:193), provides a good example. The only published report of Celtis seeds in prehistoric ISEA appear to be from East Timor and Aru, particularly during the terminal Pleistocene and mid-Holocene (Table 2); even in East Timor, where the sceds also occur in Neolithic contexts, evidence for Celtis disappears with the Early Metal Phase (Glover 1986:193). Beyond Aru and East Timor, the next closest occurrence seems to be from Yap in Negros (Paz 2005:Table 1), but this is an early historical site (Bacus 2004:130), and otherwise as far afield as Tapenkeng culture sites in Taiwan (Tsang 2007:78). Thus, the apparently rare trait of prehistoric ISEA Celtis exploitation suggests preNeolithic cultural interaction between Timor and Aru.

The third criterion is to accept the widespread occurrence of a novel archaeological phenomenon as evidence of largescale interaction and potentially a diaspora. However, even here the analysis drills down to the finest available level of detail, recognising (for instance) different types of pottery and polished stone tools rather than these two broad artefact classes per se. This fine grain of analysis differs from the approach taken by Hill et al. (2006), Soares et al. (2008) and Hill et al. (2007), whose studies respectively accept the Hoabinhian technocomplex of mainland Southeast Asia, the flake-blade tradition of ISEA, and the Taiwan-ISEA Neolithic as archaeological evidence for population dispersals (but without racial replacement) based on a geographical and chronological match with widely dispersed mtDNA clades. My current intention is to identify interaction spheres where there is repeated evidence from different archaeological traits for interaction between two (or more) places. For that reason, my maps of pre- $4000 \mathrm{BP}$ and post -4000 BP maritime interaction (Figurcs 1-6) include a template for all 
Table 3 Archaeologically attested Neolithic and earlier faunal introductions into Island Southeast Asia.

\begin{tabular}{|c|c|c|c|c|c|}
\hline Mompats & Introduse & 90019 & y.t. & $H_{10}$ & worososs \\
\hline Cuscus & East Timor & $9000 \mathrm{BP}$ & $\begin{array}{l}\text { Matju Kuru (+Uai Bobo } 2 \\
\text { pre-4000 BP) }\end{array}$ & New Guinea & O'Connor 2006; Table 4 \\
\hline Dorcopsis wallaby & Gebe. & $8500 \mathrm{BP}$ & Golo; Um Kapat Papo & of Island & Flannery et al. 1998 \\
\hline Sus celebensis & Flores & $8000 \mathrm{BP}$ & Liang Bua & $\begin{array}{l}\text { South } \\
\text { Sulawesi }\end{array}$ & $\begin{array}{l}\text { Morwood and van } \\
\text { Osterzee 2007:101 }\end{array}$ \\
\hline Cuscus & $\begin{array}{l}\text { Gebe; Morotai; } \\
\text { Halmahera }\end{array}$ & $>7000 \mathrm{BP}$ & $\begin{array}{l}\text { Golo; Um Kapat Papo; } \\
\text { Daeo 2; Siti Nafisah }\end{array}$ & New Guinea & Bellwood 1997:188-189 \\
\hline $\begin{array}{l}\text { Capra/Ovis } \\
\text { (presumably goat) }\end{array}$ & East Timor & $\begin{array}{l}7500 \mathrm{BP} ? \\
6000 \mathrm{BP} ?\end{array}$ & Beri Ceri Uato; Uai Bobo 2 & Eurasia & $\begin{array}{l}\text { Glover 1986:97, 169; } \\
\text { Table } 4\end{array}$ \\
\hline Cervus timorensis & South Sulawesi & $4000-5000 \mathrm{BP}$ & Leang Burung 1 & Java/Bali & Simons and Bulbeck 2004 \\
\hline Dorcopsis wallaby & Halmahera & $4500 \mathrm{BP}$ & Siti Nafisah & Gobe & Flannery et al. 1998 \\
\hline Cuscus & Halmahera & $4500 \mathrm{BP}$ & Siti Nafisah & $\begin{array}{l}\text { Gebe or } \\
\text { Morotai }\end{array}$ & $\begin{array}{l}\text { Pasveer and Bellwood } \\
2004: 303\end{array}$ \\
\hline Civet cat & East Timor & $4000-5000 \mathrm{BP}$ & Uai Bobo 2 & Eurasia & Table 4 \\
\hline Pig & East Timor & $\mathrm{c.} .4000 \mathrm{BP}$ & Uai Bobo 2 & $\begin{array}{l}\text { Flores/ } \\
\text { Sulawesi }\end{array}$ & Table 4; cf. Spriggs 2003 \\
\hline Sus scrofa & Sarawak ... & Neolithic & Niah & Eurasia & Barker 2005 \\
\hline Sus scrofa & South Sulawesi & Neolithic & Kalumpang & Eurasia & $\begin{array}{l}\text { Bulbeck and Nasruddin } \\
2002\end{array}$ \\
\hline Pig & Kayoa & Neolithic & Uattamdi & Eurasia & Bellwood 1997:229 \\
\hline Pig & Banda & Neolithic & Pulau Ay 1 & Eurasia & Spriggs 2007:111 \\
\hline Dog & Sarawak & Neolithic & Niah & Eurasia & Barker 2005 \\
\hline Dog & South Sulawesi & Neolithic & Minanga Sipakko & Eurasia & Simanjuntak at al. 2008 \\
\hline Dog & East Timor & Neolithic & $\begin{array}{l}\text { Beri Ceri Uato; Uai Bobo 2; } \\
\text { Matju Kuru 2 }\end{array}$ & Eurasia & Table 4; Spriggs 2007 \\
\hline Dog & Kayoa & Neolithic & Uattamdi & Eurasia & Bellwood 1997:229 \\
\hline Bos & South Sulawesi & Neolithic & Leang Burung 1 & Eurasia & Simons and Bulbeck 2004 \\
\hline Bos & East Timor & Neolithic & Beri Ceri Uato & Eurasia. & Table 4 \\
\hline Porcupine & South Sulawesi & Neolithic & Minanga Sipakko & Eurasia & Simanjuntak ot al. 2008 \\
\hline Monkey & East Timor & Neolithic & Uai Bobo 2 & Eurasia & Glover 1986 \\
\hline Cervus timorensis & East Timor & Neolithic (?) & Uai Bobo 1 & Java/ Sulawesi & Table 4 \\
\hline
\end{tabular}

Table 4 Medium to large mammal identifications, minimum numbers of individuals, in Glover's (1986:121, 158, 192) East Timor rockshelters based on the chronology outlined in Table 1. Figures in brackets include uncertain identifications.

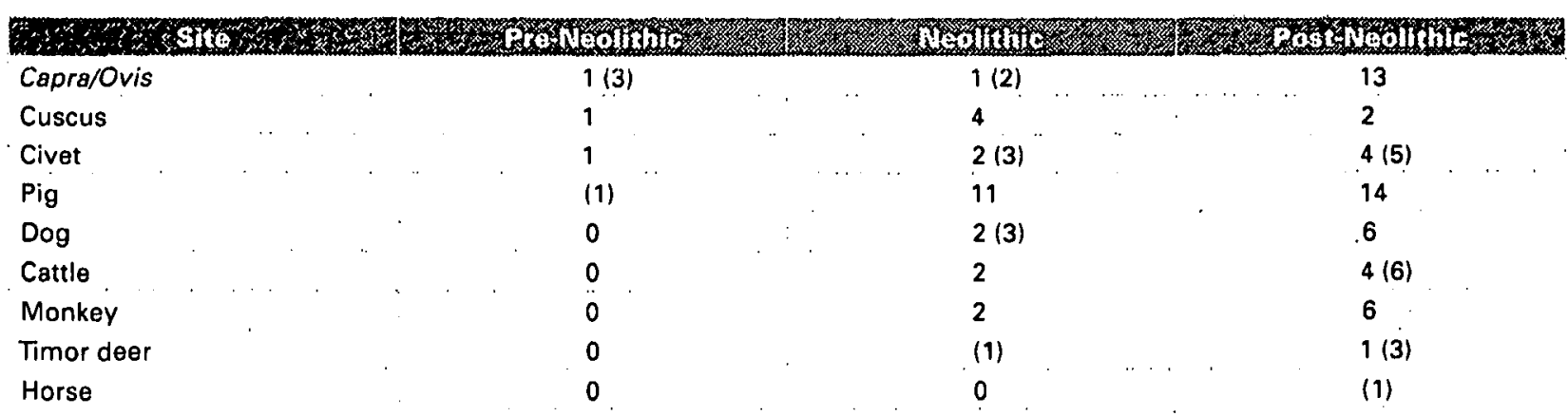


of the interaction axes evidenced for each period, although the individual maps will emphasise particular axes to assist their legibility by readers.

The main value of the current exercise is to employ a bottom-up approach to detect overarching patterns of maritime interaction. Rc-performance of the exercise at a future date may well vary the individual interaction axes suggested by the archaeological traits used here, or recognise additional interaction axes, as our knowledge of ISEA prehistory grows. Large areas such as Mindanao, eastern Sulawesi, Indonesian Borneo (Kalimantan) and Sumatra remain sparsely documented in terms of their pre-Metal Phase archaeology. The relative scarcity of open-air sites compared to caves and rockshelters, and the typically poor preservation conditions for organic remains in the open-air sites that have been excavated, are also recognised as sampling problems which, hopefully, future fieldwork will ameliorate. The present study stands or falls to the degree that it identifies patterns of maritime interaction that will be confirmed rather than falsified by future research.

\section{Tropical and Subtropical Interaction Spheres before $4000 \mathrm{BP}$}

Table 5 presents the evidence for interaction spheres that extended across the sea in ISEA and its environs during the millennia prior to $4000 \mathrm{BP}$. None of these cases is argued here to be associated with the expansion of languages, leastways languages that have left modern descendants, except where explicitly specified. In addition, all cited age estimates are based on calibrated radiocarbon dates except where otherwise specified or else quoted as a mean radiocarbon determination and standard error. The antiquity estimates presented in Table 5 are indicative approximations.

The Hagop Bilo assemblage in Sabah, dated to $18,000-12,000$ $\mathrm{BP}$, includes a class of elongate blade-like flakes (Bellwood 1997:179). This assemblage is contemporary with the late Pleistocene industry featuring blade-like flakes from Leang Sarru, in the Talaud Islands, which Tanudirjo (2001:264) conservatively dates to between 21,000 and 10,000 years ago (Figure 1). No other published ISEA industries from the terminal Pleistocene feature these blade-like flakes; the similar assemblage from Callao Cave, Luzon, dates to 26,000 years ago (Mijares 2007).

Intriguingly, blade-like flakes are absent from later assemblages in Sabah (Bellwood 1997:180), but continued in production on the Talaud Islands (at Leang Tuwo Mane'e), and then appeared in early to middle Holocene assemblages on Palawan (Duyong and Guri Caves), Cebu (Carcar), and probably Buad, Daram and surrounding islets of the central Philippines (Bulbeck et al. 2000:99-100). In proposing an interaction sphere that connected the Talaud Islands to Palawan and the central Philippines (Figure 3), I point out that it is ringed by coeval sites that lack these blade-like flakes, not only sites in Sabah, but also Paso in North Sulawesi (Bellwood 1997:185-186), Kimanis and Lubang Payau in East Kalimantan (Arifin 2004), the Cagayan Valley rockshelter assemblages in Luzon (Mijares 2007), and numerous North Moluccan sites (Bellwood 1998; Tanudirjo 2001:286-291).

This mooted maritime interaction sphere is confirmed by the evidence of obsidian exchange, at least as far as the Philippine zone is concerned (Neri 2007). Philippine archaeologists have recovered obsidian artefacts from islands lacking obsidian sources in aceramic contexts: specifically, the deeper layers of Ille on Palawan, believed to pre-date 10,000 BP; and, less securely, from the Bungiao Shelter on Mindanao and as surface collections on Cebu. The source of the chemically-tested Ille and Mindanao obsidian is unknown but would not appear to be Luzon (Figure 1). The only evidence I can find of a pre-Neolithic connection between Luzon and the islands to the south is the exploitation of the same species of nut in the Cagayan Valley sites and at Illc Cave in Palawan (Table 2; Figure 2).

Another feasible interaction sphere with terminal Pleistocene origins involves the earliest edge-ground stone tools in Southeast Asia, which are dated to between 20,000 and 10,000 BP at Niah Cave in Sarawak, and between 11,000 and 7000 BP at Bacsonian sites in North Vietnam (Mijares 2007:12, 16). Although Borneo would have still been connected by land to mainland Southeast Asia at 11,000 years ago, the lack of other edge-ground stone tools older than the mid-Holocene suggests a direct maritime connection (Figure 1).

One likely instance of early Holocene interaction traced by lithics involves sumatraliths, which are pebble tools flaked across most or all of one face (Figure 2). These occur at Togi Ndrawa on Nias Island (Forestier et al. 2005), Gua Pandan in South Sumatra (Forestier et al. 2006), the northern Sumatra shell middens (Bellwood 1997:169-170; van Heekeren 1972:86-87), and the shell middens and lowland rockshelters (such as Gua Kerbau) of the western Malay Peninsula (Adi 2000:157; Bulbeck 2003:135, 139). At Togi Ndrawa, sumatraliths are not reported from the basal Pleistocene deposit, and first appear in horizon 3, which dates from around 9000 BP. All of the other Sumatra and Malaya sumatraliths appear to be Holocene and those that can be dated with any confidence post-date $8000 \mathrm{BP}$. These points suggest expansion of the technology of invasive unifacial flaking of pebbles (resulting in sumatraliths) after post-Pleistocene sealevel rises had separated Sumatra and Malaya, and isolated Nias from the Sumatra mainland.

Our next two cases involve specific comparisons between the bone points which, as a group, occur quite frequently in Southeast Asian assemblages that post-date $11,000 \mathrm{BP}$, arguably associated with exploitation of the expanding mangrove forests of the terminal Pleistocene and early Holocene (Rabett 2005). With these bone points, a potential use as blowpipe darts has been nominated only for examples from Niah, which date predominantly to the initial Holocene (Rabett 2005:155, 181), and from South Sulawesi where bone points were manufactured as of the early Holocene (Olsen and Glover 2004). Note that an origin of blowpipe technology in Borneo would be supported on ethnographic grounds (Jett 1970). Rabett's own study of bone point technology, morphology and use-wear identified the same tool types at Niah and Khok Phanom Di in south-central Thailand (large scraped tubular points), and at Pulau Balambangan in Sabah and Khok Phanom Di (hafted woodworkers), but the much later dating of the Khok Phanom Di examples (Rabett 2005) rules out the use of these comparisons to indicate interaction spheres. The situation is more favourable in far eastern Indonesia, based on Pasveer's (2005; Pasveer and Bellwood 2004) study of the bone points from Aru, North Maluku, and Kria in New Guinea's Vogelkop. In contrast to the Aru bone points, the latter two assemblages are rich in bipoints, relatively homogeneous in their metrical attributes, have a bimodal breakage pattern consistent 
Table 5 Evidence of cross-sea interaction spheres prior to $4000 \mathrm{BP}$ in Island Southeast Asia and its environs. Continuations of these interaction spheres after $4000 \mathrm{BP}$ are not considered here.

\begin{tabular}{|c|c|c|c|c|}
\hline$A$ angas & 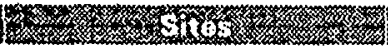 & 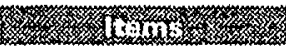 & 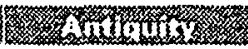 & (1) \\
\hline Sabah; Talaud islands & Hagop Bilo: Leang Sarru & Blade-like flakes & $18,000-12,000 \mathrm{BP}$ & $\begin{array}{l}\text { Bellwood 199\%; Tanudirjo } \\
2001\end{array}$ \\
\hline $\begin{array}{l}\text { Talaud Islands; Palawan; } \\
\text { central Philippines }\end{array}$ & $\begin{array}{l}\text { Leang Tuwo Mane'e; } \\
\text { Duyong Cave; Carcar }\end{array}$ & Blade-like flakes & $7000-4000 \mathrm{BP}$ & Bulbeck et al. 2000 \\
\hline Palawan; Cebu; Mindanao & Ille; Bungaio; Tagatong Hill & Obsidian & $>10,000-5000 \mathrm{BP}$ & Neri 2007 \\
\hline Luzon; Palawan & See Table 2 & Unidentified nut & $>4000 \mathrm{BP}$ & See Table 2 \\
\hline Sarawak; North Vietnam & Niah; Bacsonian sites & $\begin{array}{l}\text { Edge-ground stone } \\
\text { tools }\end{array}$ & $11,000-10,000 \mathrm{BP}$ & Mijares 2007 \\
\hline Sarawak; South Sulawesi & $\begin{array}{l}\text { Niah; Leang Burung 1; Ulu } \\
\text { Leang } 1\end{array}$ & $\begin{array}{l}\text { Mooted bone } \\
\text { blowpipe darts }\end{array}$ & $10,000-7000 \mathrm{BP}$ & $\begin{array}{l}\text { Olsen and Glover 2004; } \\
\text { Rabett } 2005\end{array}$ \\
\hline $\begin{array}{l}\text { North Maluku; New } \\
\text { Guinea }\end{array}$ & $\begin{array}{l}\text { Siti Nafisah; Daeo 2; Golo; } \\
\text { Kria }\end{array}$ & $\begin{array}{l}\text { Lashed bone } \\
\text { bipoints }\end{array}$ & :7000-4000 BP & Pasveer 2005 \\
\hline $\begin{array}{l}\text { Nias; Sumatra; West } \\
\text { Malaya }\end{array}$ & $\begin{array}{l}\text { Togi Ndrawa; Gua Pandan; } \\
\text { mid-Holocene shell } \\
\text { middens }\end{array}$ & Sumatraliths & $9000-40008 P$ & $\begin{array}{l}\text { Bulbeck 2003; Forestier } \\
\text { et al. 2005, } 2006\end{array}$ \\
\hline Sarawak; South Sulawesi & Niah; Leang Burung 1 & Fabaceae & $10,000-4500 \mathrm{BP}$ & See Table 2 \\
\hline $\begin{array}{l}\text { East Kalimantan; South } \\
\text { Sulawesi }\end{array}$ & Various sites & $\begin{array}{l}\text { Rich parietal art } \\
\text { focused on hand } \\
\text { stencils }\end{array}$ & $10,000-4000 \mathrm{BP}$ & $\begin{array}{l}\text { Bulbeck 2004; Chazine } \\
2004,2005\end{array}$ \\
\hline $\begin{array}{l}\text { East Kalimantan; South } \\
\text { Sulawesi; Java; Flores }\end{array}$ & $\begin{array}{l}\text { Kimanis; various Java and } \\
\text { Sulawesi sites; Liang Toge; } \\
\text { Gua Pandan }\end{array}$ & $\begin{array}{l}\text { Marine shell } \\
\text { scrapers }\end{array}$ & $9000-4000 \mathrm{BP}$ & $\begin{array}{l}\text { Arifin 2004; Bulbeck et al. } \\
\text { 2000; van Heekeren 1972; } \\
\text { Prasetyo } 2002\end{array}$ \\
\hline Flores; South Sulawesi & Liang Bua; Maros sites & Sus celebensis & $8000 \mathrm{BP}$ & Soe Table 3 \\
\hline Java/Bali; South Sulawesi & Leang Burung 1 & Cervus timorensis & $5000-4000 \mathrm{BP}$ & See Table 3 \\
\hline $\begin{array}{l}\text { East Timor; Flores/South } \\
\text { Sulawesi? }\end{array}$ & Uai Bobo 2 & Pig & $:>4000 \mathrm{BP}(?)$ & See Table 3 \\
\hline East Timor; Java? & Beri Ceri Uato; Uai Bobo 2 & Capra/Ovis (goat?) & $7500-6000 \mathrm{BP}(?)$ & See Table 3 \\
\hline East Timor; Java? & Uai Bobo 2 & Civet cat & $5000-4000 \mathrm{BP}$ & See Table 3 \\
\hline $\begin{array}{l}\text { New Guinea; Gebe; North } \\
\text { Maluku }\end{array}$ & See Table 3 & Dorcopsis wallaby & $8500 \mathrm{BP} ; 5500 \mathrm{BP}$ & See Table 3 \\
\hline $\begin{array}{l}\text { New Guinea; East Timor; } \\
\text { North Maluku }\end{array}$ & See Table 3 & Cuscus & $9000 \mathrm{BP}$ & See Table 3 \\
\hline Java; South Sulawesi & Numerous sites & $\begin{array}{l}\text { Pirri points; double- } \\
\text { pointed bone } \\
\text { needles }\end{array}$ & $7000-4000 \mathrm{BP}$ & $\begin{array}{l}\text { Bulbeck et al. } 2000 ; \\
\text { Prasetyo } 2002\end{array}$ \\
\hline $\begin{array}{l}\text { Rote; East Timor; East } \\
\text { Kalimantan; Aru, Flores; } \\
\text { Java }\end{array}$ & Numerous sites & $\begin{array}{l}\text { Shell beads and } \\
\text { pendants }\end{array}$ & $13,000-4000 \mathrm{BP}$ & See Tables 6-8 \\
\hline East Timor; Aru & See Table 2 & Celtis seeds ... ... & $13,000-6000 \mathrm{BP}$ & See Table 2 \\
\hline Sarawak; Vietnam & Gua Sireh & $\begin{array}{l}\text { Basket-impressed } \\
\text { pottery }\end{array}$ & $4500-4000 \mathrm{BP}$ & Datan 1990; Nguyen 2005 \\
\hline Sarawak; Vietnam. & Gua Sireh & Rice & $4500-4000 \mathrm{BP}$ & See Table 2 \\
\hline Palawan: North Vietnam & $\begin{array}{l}\text { Da But sites; Sa'gung } \\
\text { Sheiter }\end{array}$ & $\begin{array}{l}\text { Edge-ground stone } \\
\text { adzes }\end{array}$ & $6500-6000 \mathrm{BP}$ & Kress 2004; Nguyen 2005 \\
\hline Palawan; North Vietnam & $\begin{array}{l}\text { Da But sites; Duyong Cave; } \\
\text { Paredes Shelter }\end{array}$ & $\begin{array}{l}\text { Polished stone } \\
\text { adzes; shell jewelery }\end{array}$ & $6000-5000 \mathrm{BP}$ & Fox 1970; Nguyen 2005 \\
\hline $\begin{array}{l}\text { Palawan; Talaud Islands; } \\
\text { North Maluku; East Timor }\end{array}$ & $\begin{array}{l}\text { Duyong Cave: Leang } \\
\text { Tahuna; Leang Manaf; } \\
\text { Gebe; Tutuala }\end{array}$ & Shell adzes & $9000-4000 \mathrm{BP}$ & $\begin{array}{l}\text { Bellwood 1998; Fox 1970; } \\
\text { Tanudirjo } 2001\end{array}$ \\
\hline $\begin{array}{l}\text { South China; Pescadores; } \\
\text { Taiwan }\end{array}$ & $\begin{array}{l}\text { Kwangtung sites; Suogang; } \\
\text { Tapenkeng culture sites }\end{array}$ & $\begin{array}{l}\text { Cord-marked pottery; } \\
\text { clay spindle whorls }\end{array}$ & $5500-4500 \mathrm{BP}$ & $\begin{array}{l}\text { Beliwood 2005a; Tsang } \\
2005\end{array}$ \\
\hline $\begin{array}{l}\text { South China; Pescadores; } \\
\text { Taiwan }\end{array}$ & $\begin{array}{l}\text { Kwangtung sites; Suogang: } \\
\text { Tapenkeng culture sites }\end{array}$ & Rice; millet & $5500-4500 \mathrm{BP}$ & $\begin{array}{l}\text { Bellwood 2005a; Tsang } \\
2005\end{array}$ \\
\hline $\begin{array}{l}\text { South China; Pescadores; } \\
\text { Taiwan }\end{array}$ & $\begin{array}{l}\text { Kwangtung sites; Suogang; } \\
\text { Tapenkeng culture sites }\end{array}$ & $\begin{array}{l}\text { Polished stone } \\
\text { artefacts }\end{array}$ & $5500-4500 \mathrm{BP}$ & $\begin{array}{l}\text { Bellwood 2005a; Tsang } \\
2005\end{array}$ \\
\hline Northern Luzon; Taiwan & $\begin{array}{l}\text { Cagayan sites; Baxiandong } \\
\text { sites }\end{array}$ & Small flake tools & $6000-5000 \mathrm{BP}$ & Mijares 2007; Zhang 2000 \\
\hline Taiwan; northern Luzon & $\begin{array}{l}\text { Fushan culture sites; Rabel } \\
\text { Cave; Minori Cave }\end{array}$ & Plain pottery & $5000-4000 \mathrm{BP}$ & See text \\
\hline
\end{tabular}


with lashed hafting, appear to have been used predominantly as borers or engravers, and post-date $7400 \mathrm{BP}$, with a chronological focus between 7000 and 3000 BP (Figure 3).

The possibility of a Borneo-Sulawesi connection is reinforced by the botanical evidence of Fabaceae exploitation restricted to these two islands (Table 2). Additionally, Borneo and Sulawesi include the only two documented locations in ISEA with rock art galleries featuring hand stencils and painted zoomorphs as the dominant motifs. In East Kalimantan these date back to around 10,000 BP (Chazine 2005; Fage 2005); in southwest South Sulawesi, direct dating of the art has not been pursued, but the paintings are typically associated with Mesolithic cultural deposits (Bulbeck 2004a:150-151; van Heekeren 1972). Holocene interaction between East Kalimantan and South Sulawesi is confirmed by the recovery of scrapers of marine shell (the earliest associated with a radiocarbon date of $8840 \pm 250$ BP) from Kimanis (Arifin 2004:247-249), and broadly coeval rockshelter deposits at Maros in South Sulawesi (Bulbeck et al. 2000:84-87). However, in this case similar scrapers also occur in pre-ceramic contexts at a number of sites within Flores, on Java's castern tip (van Heekeren 1972:100-104, 141-146), and at Gunung Sewu in southern Java (Prasetyo 2002:185-186).

South Sulawesi was involved in at least two and possibly three of the seven faunal introductions recorded for pre-Neolithic times (Table 5). Further, both Bellwood (1997:197-198) and Bulbeck et al. (2000) drew comparisons between the Toalean of South Sulawesi, and industries in Java broadly dated to the midHolocene, based on their commonalities of unifacially retouched stone points and double-pointed bone needles (see also Prasetyo 2002). Indeed, mooted overseas connections for the Toalean tool types crop up regularly in the literature, and include Japan, in regard to the hollow-based Maros points (Bellwood 1997:200), South Asia, vis-à-vis backed microliths (Glover and Presland 1985), and northern Australia, in relation to stone and bone points (Olsen and Glover 2004). These long-distance comparisons strengthen the case for widespread maritime exchange that had enmeshed South Sulawesi by the mid-Holocene.

Shell ornaments including beads and pendants appear to date to the late Pleistocene or early Holocene at three Rote rockshelters excavated by Mahirta (2003). Table 6 summarises the relevant data. Despite the evident archaeological associations, and the lack of Neolithic dates from any of the Rote shelters, Mahirta (2003:159-163) concluded that the perforated olive shells may be pre-ceramic, but the other shell ornaments reflect a technology introduced by Austronesian settlers along with their pottery. However, except at Lua Meko, where a shell bead was recovered from the layer beneath the deepest perforated olive shell, perforated olive shells occur together with the other shell ornaments. These other shell ornaments outnumber the potsherd count by a factor of two, which strongly suggests no relationship with the pottery, and instead an association with the abundant flaked lithics. Accordingly, I follow a parsimonious interpretation of the Rote archaeological record, and date the shell artefacts (including the perforated olive shells) to the period between 15,000 (as a minimum date) and $5500 \mathrm{BP}$, unrelated to the pottery which, as noted by Spriggs (2007:110), appears to be a sparsely deposited, late Holocene intrusion.

The Rote evidence fits snugly within a well-attested tradition of marine shell ornament manufacture in southern Indonesia
(Figure 1). Additional examples from the Pleistocene/Holocene junction have been recorded in East Kalimantan, East Timor and Aru, and early to mid-Holocene specimens are known from Java and Flores (Table 7). Glover's excavations in East Timor reinforce the impression of widespread pre-Neolithic shell working even if they also indicate an increase in the number and variety of shell artefacts produced during the Neolithic (Table 8). While Glover's findings may have suggested a Neolithic dating for the fish hooks, Lene Hara yielded two Trochus fishhooks directly and stratigraphically dated to between 6000 and 10,000 BP (O'Connor 2006:78), while Jerimalai, another East Timor rockshelter, has produced an early Holocene shell fishhook (O'Connor 2007:531).

Our coverage now turns to the controversy over $4000-4500$ year old pottery, with rice husk inclusions, at Gua Sireh in Sarawak. Bellwood (1997:237-238, 2005b, 2006) has proffered two associations, both of them evidently driven more by the hunt for a historical linguistic correlation than the archaeological evidence. His first explanation proposed an origin in Malaya, based on Adelaar's (1995) suggestion of a possible affinity between Malaya's Aslian languages and Land Dayak in Sarawak; but when Adelaar pointed out that he was certainly not proposing an ancient Aslian presence in Sarawak, Bellwood (2005b, 2006:57-58) opted for a precocious emigration of Austronesians from Taiwan during its Middle Neolithic, marked by fine cord-marked pottery (cf. Hung 2005). However, if we review Datan's (1990) description of the Gua Sireh pottery, we nowhere find it described as fine, and also learn that cord-marked decorations are rare, affecting a mere $4 \%$ of decorated sherds (Datan 1990:74). Instead, basket-marked and carved paddle-impressed decorations dominate. The only point of similarity would appear to be the rarity of red-slipping (Datan 1990:72; Hung 2005).

The most parsimonious origin for Gua Sireh's early pottery and rice is North Vietnam (Figure 3). Early pottery in North Vietnam, none of it described as red-slipped, dates back to at least 6500 BP (Higham 2002:36). The Da But pottery outperforms Taiwan's pottery in matching the Gua Sireh sherds (Datan 1990), as it is described as simple, with cord-marked decorations appearing only after c. $5000 \mathrm{BP}$, alongside the older practice of impressing the vessels with unspun fibres (Nguyen 2005). Bower et al. (2006) report stable isotope evidence for rice consumption in a $\mathrm{Da}$ But culture site by 5000-6000 BP even though Vietnam's earliest rice remains post-date $5000 \mathrm{BP}$. Certainly, the origins of riziculture in mainland Southeast Asia can be conservatively dated at 4000-4500 BP (Higham 2002:94). Geographical intermediates between North Vietnam and Sarawak may be present amongst the various coastal and lowland sites of central and southern Vietnam with pottery dated to $4000-4500 \mathrm{BP}$, although, from the sources available to me, the pottery is either undescribed or else designated as cord-marked (Higham 2002:37-38, 108).

The Da But sites appear to be implicated in another maritime exchange network, consistent with their possible direct link to Sarawak. From the data in Kress (2004), the burials in the Sa'gung Shelter, Palawan, can be divided into two mutually exclusive groups (Table 9). The flexed burials are assocjated with edgeground adzes, necklaces of crocodile teeth, and a lime plug, while the other burials are associated with ceramic objects (including a Ming bowl), glass beads, and shell grave goods. Although the flexed burials are not well dated, their disposition is reminiscent 
Table 6 Summary of artefacts excavated from Rote rockshelters (Mahirta 2003). LP signifies a radiocarbon date of over 20,000 BP, TP signifies calibrated radiocarbon dates between 15,000 and $10,000 \mathrm{BP}$, while EH signifies calibrated radiocarbon dates between 8,000 and $5,500 \mathrm{BP}$.

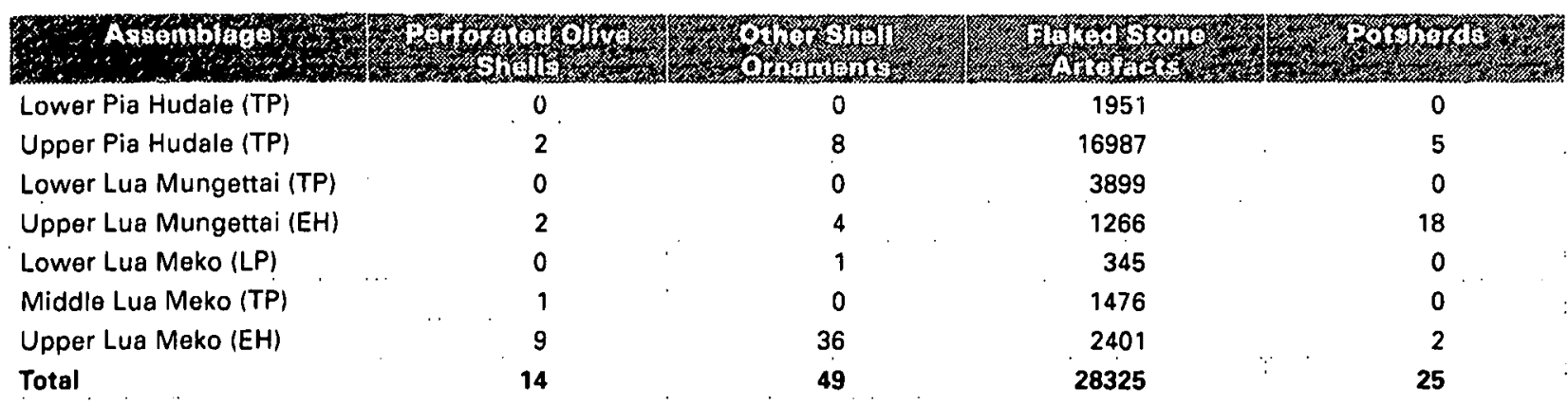

Table 7 Pre-Neolithic shell ornaments from Island Southeast Asia sites outside of Rote.

\begin{tabular}{|c|c|c|c|c|}
\hline East Kalimantan & Kimanis & 15 cowry ornaments & $12,000-5000 \mathrm{BP}$ & Arifin 2004:104, 246 \\
\hline East Timor & Matju Kuru 1 & Simple shell beads & $<13,690 \pm 130 \mathrm{BP}$ & Veth et al. 2005:184-185 \\
\hline Aru & Liang Nabulei Lisa & Terebra subulata ornament & $9750 \pm 60 \mathrm{BP}$ & O'Connor et al. 2005a:134-135 \\
\hline East Timor & Matju Kuru 2 & Trochus and Nautilus beads & $>9000 \mathrm{BP}$ & $\begin{array}{l}\text { Szabó and O'Connor } 2004: 625- \\
626 ; \text { O'Connor } 2006: 79\end{array}$ \\
\hline $\begin{array}{l}\text { Gunung Sewu; } \\
\text { Java }\end{array}$ & $\begin{array}{l}\text { Gua Braholo; Song } \\
\text { Keplek }\end{array}$ & $\begin{array}{l}\text { Drilled Pelycypods } \\
\text { ornaments }\end{array}$ & $\begin{array}{l}\text { Early/mid- } \\
\text { Holocene }\end{array}$ & Prasetyo 2002:187-188 \\
\hline East Timor & $\begin{array}{l}\text { Beri Ceri Uato; Uai } \\
\text { Bobo } 1 \& 2\end{array}$ & $\begin{array}{l}\text { Perforated shells; Nautilus } \\
\text { beads }\end{array}$ & $6500-4000 \mathrm{BP}$ & Table 8 \\
\hline Flores & $\begin{array}{l}\text { Leang Toge; Gua } \\
\text { Rundung }\end{array}$ & $\begin{array}{l}\text { Drilled shell and mother-of- } \\
\text { pearl ornaments }\end{array}$ & $\begin{array}{l}\text { Pre-ceramic } \\
(5000-40000 \text { BP?) }\end{array}$ & van Heekeren 1972:141, 146 \\
\hline
\end{tabular}

Table 8 Marine shell artefacts from Glover's (1986:75, 118, 151-152, 189) East Timor sites based on the Table 1 chronology.

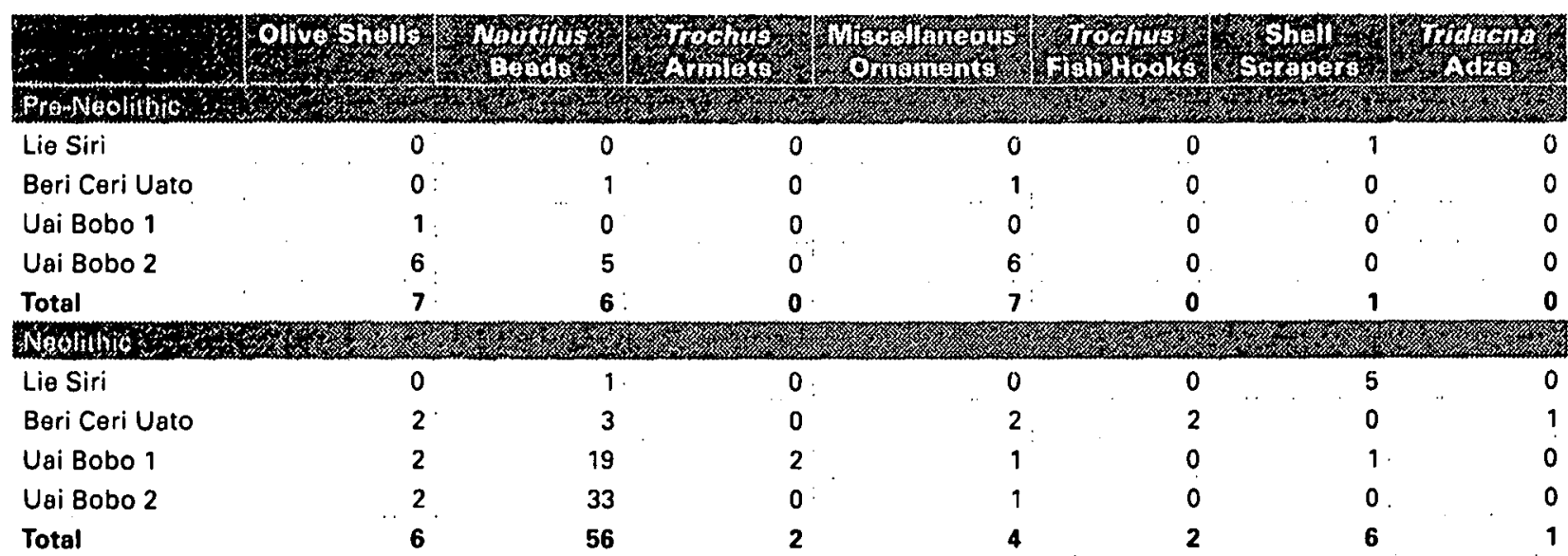

Table 9 Summary of the Sa'gung burials (Kress 2004:Table 2).

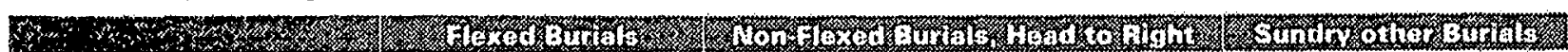

Edge-Ground Adzes

Crocodile-Tooth Necklace

Lime Plug

Ceramic Grave Goods

Shell Grave Goods

Burial with Glass Beads

5
2
1
0
0
0

$\begin{array}{ll}0 & 0 \\ 0 & 0 \\ 0 & 0 \\ 2 & 1 \\ 2 & 1 \\ 1 & 1\end{array}$


of the flexed burials associated with the Da But sites in North Vietnam (Higham 2002:37), and the lack of ceramics suggests a pre-4000 BP age. Mijares (2007:21) proposes a similarity between the Sa'gung edge-ground axes and those in Bacsonian contexts, but a more plausible connection, also in North Vietnam, may be early Da But culture, given Nguyen's information (2005:92) that the polishing of stone tools in these contexts was largely limited to polishing tool edges.

The fact that fully polished stone tools, including those with a quadrangular cross-section, predominated in late $\mathrm{Da}$ But contexts may additionally provide a source for the quadrangular polished stone adze excavated with a flexed burial at Duyong Cave, Palawan. The Duyong Cave flexed burial certainly stands out as an anomaly for 'Austronesian package' theorists: no pottery, two dates that calibrate to c.5000-6000 BP, ear discs and a breast pendant of Conus shell, and multiple Tridacna shell adzes (Bellwood 1997:221-222). Precisely these same shell artefacts were recovered with two flexed, aceramic burials at the Paredes Shelter on Langen Island immediately north of Duyong (Fox 1970:64) Intriguingly, the flexed $\mathrm{Da}$ But burials are also associated with shell jewelery (Higham 2002:37). Further, as regards the shell adzes, Bellwood (1997:222) himself suggests a relationship with the pre-ceramic tradition of shell adzes (Tridacna and Hippopus) from Golo Cave, Gebe, North Moluccas, dated to 12,000-8000 BP (see also Bellwood 1995:9, 1998) or perhaps a little later (Bellwood 2000).

There is considerable evidence for a chain of sites with early to mid-Holocene shell adzes connecting Palawan and eastern Indonesia (Figure 2). At the Sanga Sanga Island shell midden in the Sulu Archipelago, Casiño retricved five Tridacna tools, and subsequent excavation into the pre-ceramic levels yielded shell tools associated with radiocarbon dates (on marine shell) of $6650 \pm 180 \mathrm{BP}$ and 7945 $\pm 190 \mathrm{BP}$ (Solheim et al. 1979:117). In the same archipelago, Balobok Cave yielded shell tools including a Tridacna adze in a layer with a radiocarbon date of $8760 \pm 130$ BP, although the adze is of a different type from the Duyong examples (Ono 2003:200). Farther south, Tanudirjo (2001) recovered and directly dated three Tridacna adzes: the oldest determination, $6900 \pm 90 \mathrm{BP}$, was for a surface find from leang Manaf, which yielded just one potsherd upon excavation (Sanana Island, southeast of Halmahera); the second oldest determination, 4367-4484 cal BP, was for an adze recovered stratigraphically beneath the decpest pottery deemed to be in situ (Leang Tahuna, Talaud Islands); while the youngest determination, 3750-4150 cal BP, was associated with in situ pottery at Waylia, on the same island as Leang Manaf. Tanudirjo (2001) argued that these adzes had been made during the Neolithic and Metal Phase on old shell, but this argument would dismiss as coincidence the fact that the younger their direct dating, the stronger the association with pottery. In this paper I accept the direct dates on the Leang Manaf and Leang Tahuna adzes as reasonable evidence for their pre $-4000 \mathrm{BP}$ antiquity, as well as the direct dating of $8600 \pm 245$ BP for a Tridacna adze found on the surface at Tutuala, East Timor (O'Connor 2006:81).

The archaeologically best-attested interaction sphere to be considered here stretched from coastal South China across the Pescadores to the coastal fringes of Taiwan (Figure 3). The association of pottery, cereal agriculture, polished stone artefacts and other Neolithic items (Table 5) is well described in numerous sources, and needs no belabouring here. I follow Tsang (2005) in sourcing Taiwan's Tapenkeng or early Neolithic culture to coastal Kwangtung. I also endorse the emphasis by Rolett et al. (2002) on the maritime aspect of this interaction sphere that straddled the Taiwan Strait, but I disagree with these authors (2002:316-317) on its precociousness - instead it falls into a pattern encountered numerous times to the south.

There are very good grounds for identifying this interaction sphere with the PAN homeland. It is geographically discrete, matches the subtropical nature of the PAN lexicon reconstructed by historical linguists (Blust 1995), and would incorporate both the maritime (including sailing) and terrestrial components present in that lexicon. In particular, it resolves the peculiar anomaly in the standard interpretation of early Austronesian dispersal, whereby nine branches had remained stuck on Taiwan while one, PMP, alone colonised the southern seas from Madagascar to Easter Island. Instead, under the present proposal, PMP would have retained the primitive Austronesian orientation, while the 'stay-at-home' Taiwan language branches would relate to Taiwan's colonisation from the island's various coastal quarters, equipped with a material culture brought across the Strait of Taiwan.

Prior to $4000 \mathrm{BP}$, the only likely connection between Taiwan and ISEA with evidence for interaction in both directions, confirming the connection, involves North Luzon (Figure 3 ). The Cagayan Valley in Luzon has sparse pottery, not described as red-slipped, associated with flaked lithics and radiocarbon dates that calibrate to c.4000-5000 BP at two sites: Rabel Cave and Minori Cave. Rabel Cave is particularly hard to dismiss as there are two separate but indistinguishable dates which calibratc to this range, and no suggestion of any pre-ceramic occupation (sce Mijares 2007:33-35; Spriggs 2003). Evidence for an influence from Luzon on coastal Taiwan comes from the Baxiandong sites on Taiwan's eastern coast. All the published radiocarbon dates (Zhang 2000) calibrate to a tight range between 5000 and 6000 $\mathrm{BP}$, and the lithics are dominated by small flakes including points, bipolar flakes and scrapers (Zhang 2000). These assemblages evidently reflect an intrusive culture, contrasting with Taiwan's older, Hoabinhian-like 'Changpanian culture' (cf. Bellwood 1997:170; Rolett et al. 2002), and they post-date any similar industries on mainland China by thousands of years (Zhang 2000). North Luzon, where similar, undifferentiated flake tools were knapped throughout the Holocene (Mijares 2007), would be the logical source (see also Soares et al. 2008). The initiators for this interaction sphere would appear to have been based in Luzon rather than Taiwan, with only the faintest echo of Taiwan's burgeoning Neolithic reaching Luzon pre-4000 BP. This straightforward inference matches the much greater ease of maritime travel from Luzon to Taiwan than in the opposite direction (Solheim et al. 1979:146-150).

There are two other cases of a strong correlation between the interaction spheres outlined in Figures 1 and 3, and the region's prevailing currents as described by Solheim et al. (1979:145-155). These are the connections from Palawan to East Timor, and from Borneo to southwest Sulawesi (plus Java and Flores), which respectively correspond to the prevailing movement of wind and current across the Sulawesi Sea and through the Macassar Strait.

The first case typically involves sites with abundant marine shell refuse and has tools of marine shell as its particular insignia. 
Diffusion of a relatively structured stone flaking technology is inferred for the northern half, where isotropic stone sources are present (in stark contrast to the northern Moluccas), but the only suggestion of maritime trade is some movement of obsidian across the Philippines. That is, this interaction sphere evidently involved the movement of 'ideas' (read: artisans) rather than goods - artisans who could well have belonged to raft-using maritime communities similar to those proposed by Solheim et al. (1979:145-155). However, I can find no evidence that the Palawan-Talaud-Moluccan axis was any kind of nursery for large-scale developments in Southeast Asia. Instead, it appears to represent a specialised adaptation to a belt of islands which are typically small and depauperate in terrestrial resources. Most of these islands' resources would have been rapidly depleted by pedestrian forager populations; maritime transport would have been a vital requirement both to expand the breadth of foraging niches and to link groups of islands into the single range of a forager group.

The Macassar Strait sphere has a totally different character. Borneo and Sulawesi (which is visible from Borneo at certain locations) are large islands with a rich terrestrial ecology; the utilised resources recorded archaeologically at the sites are predominantly terrestrial; and the technological commonalities have a terrestrial focus. The maritime aspect, while secondary,

Table 10 Evidence of cross-sea interaction spheres c.2500 to $4000 \mathrm{BP}$ in Island Southeast Asia.

\begin{tabular}{|c|c|c|c|}
\hline $\begin{array}{l}\text { Taiwan; northern Luzon; } \\
\text { Saipan }\end{array}$ & $\begin{array}{l}\text { Taiwan sites; Andarayan; } \\
\text { Chalan Piao }\end{array}$ & Rice & Bellwood 2005a; Blench 2005 \\
\hline $\begin{array}{l}\text { Taiwan; Batanes; northern } \\
\text { Luzon }\end{array}$ & $\begin{array}{l}\text { Taiwan; Batanes; Cagayan } \\
\text { Valley sites }\end{array}$ & $\begin{array}{l}\text { Clay spindle whorls, discs } \\
\text { and pendants; stone net } \\
\text { sinkers }\end{array}$ & $\begin{array}{l}\text { Bellwood and Dizon 2005; } \\
\text { Hung 2005; Mijares } 2007\end{array}$ \\
\hline $\begin{array}{l}\text { Taiwan; Batanes; Luzon; } \\
\text { Palawan }\end{array}$ & Multiple & $\begin{array}{l}\text { Taiwan nephrite beads and } \\
\text { bracelets }\end{array}$ & Hung et al. 2007 \\
\hline Taiwan; Batanes; Sulawesi & $\begin{array}{l}\text { Taiwan and Batanes sites; } \\
\text { Kalumpang }\end{array}$ & Polished slate & $\begin{array}{l}\text { Bellwood and Dizon 2005; } \\
\text { Bulbeck and Nasruddin } 2002\end{array}$ \\
\hline $\begin{array}{l}\text { Taiwan; Batanes; Luzon; } \\
\text { Sarawak; Sulawesi }\end{array}$ & $\begin{array}{l}\text { Various sites including Niah } \\
\text { and Kalumpang }\end{array}$ & Stone barkcloth beaters & $\begin{array}{l}\text { Bellwood 1997; Bellwood } \\
\text { and Dizon 2005; Mijares } 2007\end{array}$ \\
\hline Taiwan; Batanes & Taiwan and Batanes sites & $\begin{array}{l}\text { Green nephrite polished } \\
\text { adzes }\end{array}$ & Bellwood and Dizon 2005 \\
\hline Batanes; northern Luzon & Anaro; Irigayen & Metamorphic polished adzes & Bellwood and Dizon 2005 \\
\hline $\begin{array}{l}\text { Southern Luzon; Langen } \\
\text { Island }\end{array}$ & Various sites; Leta Leta & $\begin{array}{l}\text { White nephrite polished } \\
\text { adzes }\end{array}$ & Fox 1970 \\
\hline $\begin{array}{l}\text { Sulawesi; Java; southern } \\
\text { Sumatra }\end{array}$ & $\begin{array}{l}\text { Kalumpang, plus various } \\
\text { other sites }\end{array}$ & $\begin{array}{l}\text { Polished adzes of fine } \\
\text { siliceous stone }\end{array}$ & van Heekeren 1972 \\
\hline $\begin{array}{l}\text { Taiwan; Philippines; Borneo; } \\
\text { Sumatra; east Java and Bali; } \\
\text { East Timor; Kayao }\end{array}$ & Numerous & $\begin{array}{l}\text { Polished.adzes mainly of } \\
\text { volcanic stone }\end{array}$ & $\begin{array}{l}\text { Bellwood 1997; Mijares 2007; } \\
\text { van Heekeren } 1972\end{array}$ \\
\hline $\begin{array}{l}\text { Taiwan; south Vietnam; } \\
\text { eastern Indo-Malaysia; } \\
\text { Pacific }\end{array}$ & Numerous & Red-slipped pottery & $\begin{array}{l}\text { Bellwood 1997, 2005a; } \\
\text { Solheim } 2006\end{array}$ \\
\hline $\begin{array}{l}\text { Borneo; Malaya, Sumatra; } \\
\text { Java }\end{array}$ & Numerous & Paddle-impressed pottery & Bellwood 1997 \\
\hline Taiwan; northern Luzon & Fengpitou; Cagayan sites & Black pottery & Mijares 2007 \\
\hline Flores; East Timor & Liang Bua; East Timor sites & Unslipped pottery & Glover 1986; Soejono 1985 \\
\hline $\begin{array}{l}\text { Luzon; Sabah; Langen Island; } \\
\text { Palawan; East Timor }\end{array}$ & $\begin{array}{l}\text { Arku; Callao; Leta Leta; } \\
\text { Duyong, Bukit Tengkorak; } \\
\text { Table } 7 \text { sites }\end{array}$ & Shell beads & $\begin{array}{l}\text { Bellwood 1997; Glover 1986; } \\
\text { Mijares } 2007\end{array}$ \\
\hline $\begin{array}{l}\text { Sabah; Talaud Islands; } \\
\text { Sulawesi; southern } \\
\text { Philippines }\end{array}$ & $\begin{array}{l}\text { Bukit Tengkorak; Leang Tuwo } \\
\text { Mane'e; Kalumpang; various } \\
\text { sites }\end{array}$ & Obsidian & $\begin{array}{l}\text { Bellwood 1997; Neri } 2007 \text {; } \\
\text { Simanjuntak et al. } 2008\end{array}$ \\
\hline $\begin{array}{l}\text { Sarawak; South Sulawesi; } \\
\text { North Maluku; East Timor }\end{array}$ & See Table 3 & $\begin{array}{l}\text { Dogs; pigs; Bos; porcupines; } \\
\text { monkeys; deer (?) }\end{array}$ & See Table 3 \\
\hline $\begin{array}{l}\text { South Sulawesi; Java; East } \\
\text { Timor }\end{array}$ & See Table 2 & Candlenuts & See Table 2 \\
\hline South Sulawesi; Central Java & Numerous & $\begin{array}{l}\text { Hollow-based stone } \\
\text { arrowheads }\end{array}$ & $\begin{array}{l}\text { Bulbeck et al. 2000; Prasetyo } \\
2002\end{array}$ \\
\hline $\begin{array}{l}\text { East Timor; Seram; Kei; Buru; } \\
\text { southwest New Guinea }\end{array}$ & Multiple & $\begin{array}{l}\text { Early Austronesian Painting } \\
\text { Tradition }\end{array}$ & $\begin{array}{l}\text { Ballard 1988; O'Connor and } \\
\text { Vasco Oliviera } 2007\end{array}$ \\
\hline
\end{tabular}


was nonetheless the essential ingredient to transport people across the Strait.

Here we seem to have archaeological confirmation of Oppenheimer's (1998) hypothesis of a population dispersal triggered by the drowning of Sundaland, especially as the available dates are older in Borneo than in Sulawesi, and reach back to the onset of the Holocene. The suggested dispersal of edge-ground tool technology from Sarawak to North Vietnam at the end of the Pleistocene, and blade-like flake technology connecting Sabah and the Talaud Islands as of the Late Glacial Maximum, could also relate to population dispersals associated with rising sea-levels. True, the creation of vast lengths of additional coastline during periods of sea-level rise would have expanded the potential for coastally-adapted foragers, and this would explain the lack of evidence for ancient Borneo links to Malaya or Sumatra, or directly to Java. As the rising seas deluged the intervening lowlands, there would have been a centrifugal withdrawal of populations to the emergent coastlines. However, northern and eastern Borneo would have merely experienced the drowning of coastal land without compensatory coastline expansion. This would have created conflicts over land where hinterland-adapted populations now found themselves hemmed in by an unfamiliar habitat which itself ushered in newcomers specifically adapted to that environment. A capacity for systematic maritime travel would often have been highly beneficial both for the reconnaissance of the newly created littoral niches and, where necessary, temporary or permanent evacuation of those niches under dispute.

In contrast to the Sulawesi Sea and Macassar Strait spheres, the Da But-centred, Neolithic interaction spheres to Palawan and Sarawak cut across the prevailing winds and currents of the South China Sea. This is a difficult point to accommodate, unless we infer mid-Holocene sailing technology. The resulting enhanced capacity to exploit the fruits of the sea indeed helps to explain the evidence for millennia of densely settled, sedentary Neolithic 'foragers' along the seaboard of northern and central Victnam (cf. Higham 2002:36-38). While there is an echo here of Solheim's PAN homeland (noted above), his proposed link between Sarawak and the Philippines lacks archaeological confirmation, and Luzon in particular appears rather isolated from the islands farther south.

The mid-Holocene nursery for sailing in the region appears to have been the shoreline from North Vietnam to southwest China (see also Chen 2002), consistent with the rich Neolithic assemblages dated to $5000 \mathrm{BP}$ and earlier along this coastal stretch Accepting this addition to Figures 1 to 3 , we could characterise the early maritime network as a quadrangle with its sides connecting North Vietnam to Taiwan, Taiwan to New Guinea's Vogelkop, the Vogelkop to Java, and Java to North Vietnam, which was also the source of a cross-cutting link to Palawan. While this depiction would indicate widespread maritime travel and cultural exchange, archacological evidence for richly interconnected maritime networks, and the macro-scale dispersals that mark a diaspora, post-dates $4000 \mathrm{BP}$, as we shall now see.

\section{Maritime Interaction Spheres 2500-4000 BP}

Our survey of archaeologically attested interaction spheres post-dating $4000 \mathrm{BP}$ will proceed from north to south. I use a cut-off date of c. 2500 BP for items listed in Table 10. After 2500
$\mathrm{BP}$, with the spread of metallurgy widely across ISEA, and the establishment of trade routes which ultimately connected the Mediterranean to China, we would be dealing with a totally different world from the Neolithic. Reference will, however, be madc to where Neolithic trading patterns persisted or indeed expanded after $2500 \mathrm{BP}$.

Rice remains in sherds are directly dated to around $3500 \mathrm{BP}$ in North Luzon ( $\mathrm{Paz} 2002$ ) and a similar age in the Marianas (Blench 2005:36), and presumably represent echoes of Taiwan riziculture (Figure 4). The uncertainly dated Niah sherd with a rice grain in its temper (Barker 2005:101) is not included here because it hardly implies an overseas derivation, given that rice is archaeologically well attested at Gua Sireh and in evidence before 4000 BP (Table 2). Sarawak would also be the likely source for Neolithic rice in South Sulawesi, should confirmation be found for the tentative dating by Paz (2005) of 4000 BP for some grains from Ulu Leang 1. An early first millennium $B C$ dating for rice husk from Sembiran in Bali appears too early for the site's chronology, especially as the husk was contained in non-local pottery probably imported from India (Bellwood et al. 1992:166). Otherwise, all age determinations for rice in ISEA probably postdate 2500 BP (Glover 1985:272; Paz 2002:227, 2005:112).

A rich package of material culture arrived on the Batanes, almost certainly from Taiwan, during the Neolithic (Bellwood and Dizon 2005). Some of these items, such as spindle whorls and discs of clay, and net sinkers, appear to have penetrated farther south to northern Luzon (Hung 2005; Mijares 2007), but no farther. Clay pendants probably belong here as well, even though they found their way farther south to Palawan by the Early Metal Phase (Fox 1970:147). A wider distribution applies to valuables manufactured from Taiwan nephrite, which include beads and bracelets from Neolithic contexts across Taiwan and south into the Philippines as far as Palawan (Figure 5). The trade in Taiwan nephrite continued to expand during the Early Metal Phase, with lingling-o ear pendants, some manufactured in the Batanes from imported nephrite, distributed as far as Sarawak (Niah Cave), coastal Vietnam, Cambodia and southern Thailand (Hung et al. 2007).

Polished slate artefacts (Figure 6) can be viewed in two ways. Taiwan slate itself was evidently imported to the Batanes and worked there, but the wider distribution of the technology extended to the Kalumpang sites in Sulawesi, albeit bypassing the Philippines south of the Batanes (Bellwood 1997:227; Bellwood and Dizon 2005). Barkcloth beaters of stone show a similar distribution in the islands (they are additionally widespread on mainland Southeast Asia), with the horned variety a specific feature of ISEA sites to the south of Taiwan (see Bellwood 1997; Bellwood and Dizon 2005:22; Mijares 2007; van Heekeren 1972:165-166).

The technology of polished stone adzes extended across a very wide area of Taiwan, ISEA and the Pacific during the Neolithic (Bellwood 1978, 1997, 1998; Bellwood and Dizon 2005; Bulbeck 2008; Clark 2005; Fox 1970:126, 177; Glover 1986:112; Guillard et al. 2006; Hung 2004; lizuka and Hung 2005; Mijares 2007; Simanjuntak et al. 2008; van Heekeren 1972:168-170, 187), but it is far from clear that Taiwan was the single source. Objections to any such notion include the pre-ceramic presence of this artefact class in Palawan, the widespread occurrence of polished adzes on mainland Southeast Asia, and the differences in the stone 
utilised. While adzes of volcanic stone occur across a wide area from southern Taiwan in the north, to West Sumatra in the west, Besuki, Flores and East Timor in the south, and Micronesia in the east, locally used stone sources include green nephrite in Taiwan and the Batanes, pale grey metamorphic stone in the Batanes and north Luzon, local white nephrite in southern Luzon (with two from a Neolithic context at Leta Leta Cave on Langen Island), and semi-precious siliceous stone in southern Sumatra, Java and at Kalumpang. For present purposes I recognise five interisland spheres, involving polished adzes of volcanic stone across most of the region (and the Pacific), and smaller spheres characterised by adzes of fine chert, Taiwan nephrite, white nephrite, and grey metamorphic stone (Figure 6).

Comparative analysis of the adzes in terms of morphology and cross-section lies beyond the scope of this paper, but may suggest a similarly dissected distribution, with stepped adzes largely restricted to Taiwan, the Batanes and northern Luzon (Bellwood 1997:215-221; Bellwood and Dizon 2005), round axes common in Sarawak and Wallacea from the Philippines southwards, as well as the Pacific, and rectangular cross-section adzes as the most common form in the western Archipelago (Bellwood 1978:283; van Heekeren 1972:168-172). A complication, of course, is that many of the ISEA adzes would have been manufactured during the Early Metal Phase, as noted by various commentators.

Pottery also suggests internal differentiation within its broader distribution (Figure 4). Mijares (2007:80) relates the black pottery present in northern Luzon by $3500 \mathrm{BP}$ to similar pottery in southwest Taiwan dating back to $3800 \mathrm{BP}$. Such pottery is not noted for the Batanes, even though the oldest pottery here may slightly pre-date 4000 BP (Spriggs 2007:108). The Batanes pottery instead belongs to the red-slipped pottery tradition which has been documented across a huge swathe of the Pacific as far as western Polynesia, as well as Wallacea and adjoining regions, with extensions into eastern Java (Bellwood 2005a:135139; Spriggs 2007:113-114) and southern Vietnam (Solheim 2006:111-113). Red-slipped pottery, however, has a minimal presence in Borneo (outside of Sabah), Malaya, western Java and Sumatra, where a tradition of paddle-impressed pottery, with its origins probably associated with the Gua Sireh pottery, held sway (Arifin 2004; Bellwood 1997:231, 2005a:139; Chazine 2005; Datan 1990; Forestier et al. 2006). These two Neolithic pottery complexes, which respectively correspond to Anderson's (2005) 'Neolithic B' and 'Neolithic A', were not hermetically-sealed, as suggested by small amounts of paddle-impressed sherds found in Sabah, Kalumpang and Palawan (Bellwood 1997:227; Bulbeck and Nasruddin 2002; Solheim 2006:104), and some incised red-slipped pottery from Pondok Selabe 1 in South Sumatra (Simanjuntak et al. 2006: Foto 14). Finally, a fourth interaction sphere characterised by mainly unslipped, occasionally burnished pottery appears to be characteristic of the Neolithic of Flores (Soejono 1985) and East Timor (Glover 1986). With reasonable samples of Neolithic pottery now known across the Indo-Malaysian Archipelago, detailed earthenware comparisons should be highly rewarding in delineating interaction spheres, but lie beyond the scope of this contribution.

Neolithic shell beads, albeit unreported from Taiwan or the Batanes, are recorded in Luzon (Mijares 2007), Sabah, and East Timor (Figure 5), as well as the west Pacific as part of the 'Lapita cultural complex' (Bellwood 1997:224-230; Ono 2003).
A likely source for ISEA's shell-bead technology is East Timor, where these beads were manufactured throughout the Holocene (Tables 7-8). On the other hand, evidence for shell tools in ISEA ceramic contexts is patchy. The two Tridacna adzcs from Waylia (noted above) and Glover's East Timor sites (Table 8) may be relicts from the technology's pre-Neolithic distribution. In the North Moluccas, a new class of shell adzes made of Cassis cornuta lips, with Pacific parallels, appeared after 3000 BP (Bellwood 1997:188). Bellwood (1997:224) reports shell adzcs and a possible fish hook from Bukit Tengkorak in Sabah, but Ono (2003:197) emphasises the site's scarcity of shell tools. A fossil shell adze from Anaro 2 in the Batanes (Bellwood and Dizon 2005:12-13) would actually be made of stone rather than shell.

ISEA obsidian exchange came to scholarly renown with the revelation that some of the obsidian excavated in Bukit Tengkorak had originated from Talasea, New Britain (Bellwood and Koon 1989). The $6500 \mathrm{~km}$ distribution of Talasea obsidian at c. 3000 BP from Borneo to Fiji, making it the most widely distributed material in the Neolithic world, should surely have opened eyes to the uniqueness of the Austronesian diaspora. Bukit Tengorak also yielded a second type of obsidian, possibly from the Admiralty Islands (Tykot and Chia 1997), although its concentration in the site's lower levels, and chemical match with obsidian imported to the Talaud Islands on the eve of the Neolithic (Bulbeck et al. 2000:99; Ono 2004:79), would suggest a more local source. Exogenous obsidian, presumably from overseas, is also known in Neolithic contexts from Minanga Sipakko (Simanjuntak et al. 2008) and Leang Lampoa (Bulbeck 2004a) in Sulawesi, and the Philippines south of Luzon (Neri 2007) (Figure 5). Obsidian was also being moved across Luzon (Neri 2007), Sumatra (Forestier $e t$ al. 2006) and Timor (Glover 1986) during the Neolithic, but we do not know yet whether through overland or maritime trade.

Transport of fauna was a feature of the ISEA Ncolithic, but as previously noted the evidence for Taiwan as a source is yet to be adduced (Table 3). Apart from rice in the north of the region, the only suggestion of a Neolithic, plant-based interaction sphere involves the occurrence of candlenuts in Java, Sulawesi and Timor (Table 2). In this context, the Sulawesi-Java connection would be confirmed by the hollow-based, bifacially retouched stone points which are a feature of the South Sulawesi Toalean until 35004000 BP (Bulbeck 2004a; Bulbeck et al. 2000), and which appear to date specifically to the Neolithic in Java (Forestier 2007:70; Prasetyo 2002; van Heekeren 1972:169). Although the bifacial trimming of the Java arrowheads is more invasive, the case for a Toalean influence is strengthened by the pre-ceramic ToaleanJava connection noted previously.

Finally, the 'Austronesian Painting Tradition' features hand stencils, abstract designs, and anthropomorphs evidently engaged in rites or travelling in boats, painted on high cliffs overlooking the sea. Sites with all of these features circumscribe the Banda Sea in ISEA (East Timor, Buru, Seram, southwest New Guinea, and $\mathrm{Kci}$ ) and extend to the western Pacific, including Vanuatu, where they pre-date 1500 BP (Ballard 1988; O'Connor and Vasco Oliveira 2007). As a later development in ISEA, the site location shifted to rockshelters and hand. stencils dropped out of the repertoire. This development is dated to the Early Metal Phase at Niah's Painted Cave (Pyatt et al. 2005) and at Racolo in East Timor (O'Connor and Vasco Oliveira 2007:400), and is probably even more recent at Gua Sireh in Sarawak (Datan 1990). 
Thus it would be reasonable to assign a post-Neolithic date to the tradition in the two locations where it co-occurs with the earlier hand stencil/zoomorph tradition in ISEA, viz. the rockshelters of East Kalimantan (Chazine 2004:167-168) and South Sulawesi, especially Pangkajene (Bulbeck 2004a:151; Sumantri 1996). On current evidence, the Neolithic manifestation of the Austronesian Painting Tradition in ISEA would appear to have been restricted to the Banda Sea.

An overall view of the Neolithic interaction axes (Figures 4-6) reveals a strong geographical coincidence with the distribution of ISEA Austronesian languages, such that identification with the Malayo-Polynesian diaspora could hardly be doubted. On the other hand, the overlapping complexity of the interaction axes would abnegate the suggestion of a single interaction sphere, which we would expect had Austronesian traders sailed from one corner of ISEA to the other, or had farmers (or sailors) expanded relentlessly from a single source. There appears to be some structure within the total network, including a far northern sphere (from Taiwan to northern Luzon), a Wallacean sphere from the Batanes to East Timor, a western sphere (including most of Sumatra, Java and Borneo), and a Java-Sulawesi sphere (linking the two previously mentioned spheres). This apparent structure evinces intriguing parallels with Pawley's (2002:260262) scenario for the diversification of the Malayo-Polynesian languages; unfortunately, detailed comparisons lie beyond the scope of this paper.

Evidently, the ISEA Austronesian diaspora had very little to do with the migration of a farming complex, and everything to do with the traffic of valuable goods (including fauna) and technology (cf. Spriggs 2007:106). Adzes suitable for boatbuilding pervaded ISEA, whether as the widely distributed polished adzes of volcanic stone, or the shell adzes of the northern Moluccas and East Timor. Obsidian, fine stone point technology, net sinkers, and personal ornaments were also exchanged during the Neolithic. Given the very sparse evidence for any transport of crops, the major contribution to the ISEA subsistence economy during the Neolithic would appear to have been an enhanced capacity to exploit the fruits of the sea, thanks to the widespread availability of advanced sailing technology ( $\mathrm{cf}$. Pawley 2002:265). Should future archaeological research recover evidence of more intensive plant exploitation in ISEA with the advent of the Neolithic, such a finding need not contradict my emphasis on the period's maritime orientation. The enhanced availability of exotic goods during the Neolithic would have stimulated food production so as to provide victuals for visiting and departing traders, and to augment the economic basis of the more complex social organisation that presumably accompanied the ISEA Neolithic.

\section{Evidence from Biological Anthropology}

Proponents of the theory of a migration of Austronesian Mongoloid farmers to ISEA place considerable emphasis on the region's 'Negritos' populations, presumed to be descended from the indigenous 'Australo-melanesoid' foragers (e.g. Bellwood 1997; Matsumura and Hudson 2005; Mijares 2007). This argument however pays scant regard to the location details of the Negritos. Such populations, characterised by dark skin and woolly hair, are absent from the former subcontinent of Sundaland and the neighbouring large island of Sulawesi, and instead ring this region with presences in the Philippines, south Cambodia, Malaya, the Andamans, Nusatenggara and the Moluccas (Bulbeck 1999). The persistence of numerous Negrito groups in the Philippines until ethnographic times is particularly anomalous, since surely here the immigrant Mongoloid farmers should have replaced or absorbed the resident Australo-melanesoid foragers before continuing their demic diffusion to islands farther south. Sumatra and Borneo both have populations of 'Mongoloids' dedicated to traditional foraging (the Kubu and Penan), not Australo-melanesoids as would be expected. This last anomaly prompted Bellwood (2005a:37-39) to propose that the original Borneo rainforest foragers had somehow perished without trace, leaving the rainforest niche available for occupation by the Mongoloid Penan - despite the clear archaeological (Arifin 2004; Barker 2005) and osteological (Manser 2005) evidence for continuity of Borneo rainforest foragers from the late Pleistocene/ early Holocene to modern times.

There is a simple solution to the anomalies observed above; the occupation of former Sundaland by populations which were Mongoloid, at least in terms of their external phenotype. Sulawesi could also be brought into the equation based on its archaeological evidence for early to mid-Holocene interaction with Borneo and Java. Oppenheimer (2004a:255-262) presents mtDNA evidence for a circa Late Glacial Maximum incursion of populations from mainland East Asia into Sundaland. It should also be observed that much of Sundaland would have been covered by savannah or open forest during the last millennia of the Pleistocene (Bird et al. 2005), quite different from the closed forests associated ethnographically with Negrito foragers. Osteologically, evidence for pre-Neolithic Australo-melanesoids in Sulawesi or the Sundaland region is weak (Bulbeck 2004b, 2005; Storm 1995). Widianto's (2002) claim of predominantly Australo-melanesoid burials (as well as one Mongoloid) from pre-Neolithic Gunung Sewu in Java is unaccompanied by any metrical data. Manser's (2005; Krigbaum and Manser 2005) demonstration of Southeast Asian or Polynesian affinities for the pre-ceramic Niah West Mouth crania is a far more informative finding.

The genetic evidence on the question of a Neolithic racial replacement (complete or otherwise, cf. Bellwood and Diamond 2005) in ISEA, due to demic diffusion from Taiwan, has been extensively debated (e.g. Oppenheimer and Richards 2002; Oppenheimer 2004b; Spriggs 2007). Currently, the last word on the debate, based on the study of nearly $1000 \mathrm{mtDNA}$ control region sequences from ISEA and Taiwan, comes from Hill et al. (2007) who demonstrate that the maximum proportion of the mtDNA gene pool in ISEA attributable to population expansion from Taiwan is $20 \%$. This finding would be consistent with the archaeological evidence that Taiwan had an intense but localised impact, during the Neolithic, on the northern Philippines, and a much fainter influence farther south (whether directly, or as a cascading effect from the Batanes and Luzon). It is also important to note that Taiwan's influence on ISEA may have increased rather than declined during the Early Metal Phase. It is during this time that large populations built up on Taiwan (Bellwood 2001:300; Tsang 2000), with a concomitant increase in the capacity for sustained emigration, and, as reviewed above, it is then that Taiwan jade and certain Taiwan-derived artefact types reached their widest distribution. The proportions of the $20 \%$ maximum $m$ tDNA impact of Taiwan on ISEA, to be split 


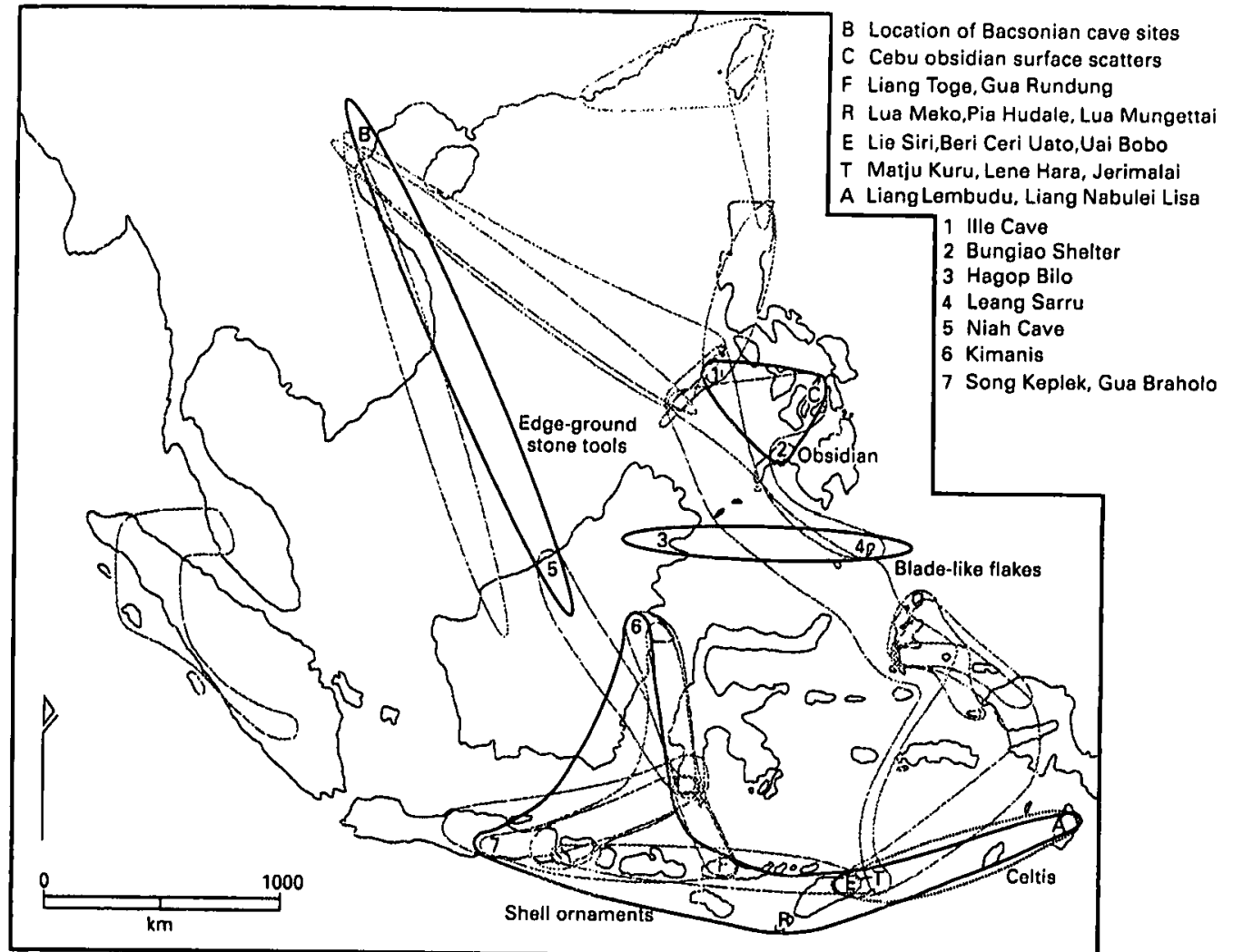

Figure 1 Maritime interaction axes in ISEA and adjacent regions with terminal Pleistocene origins.

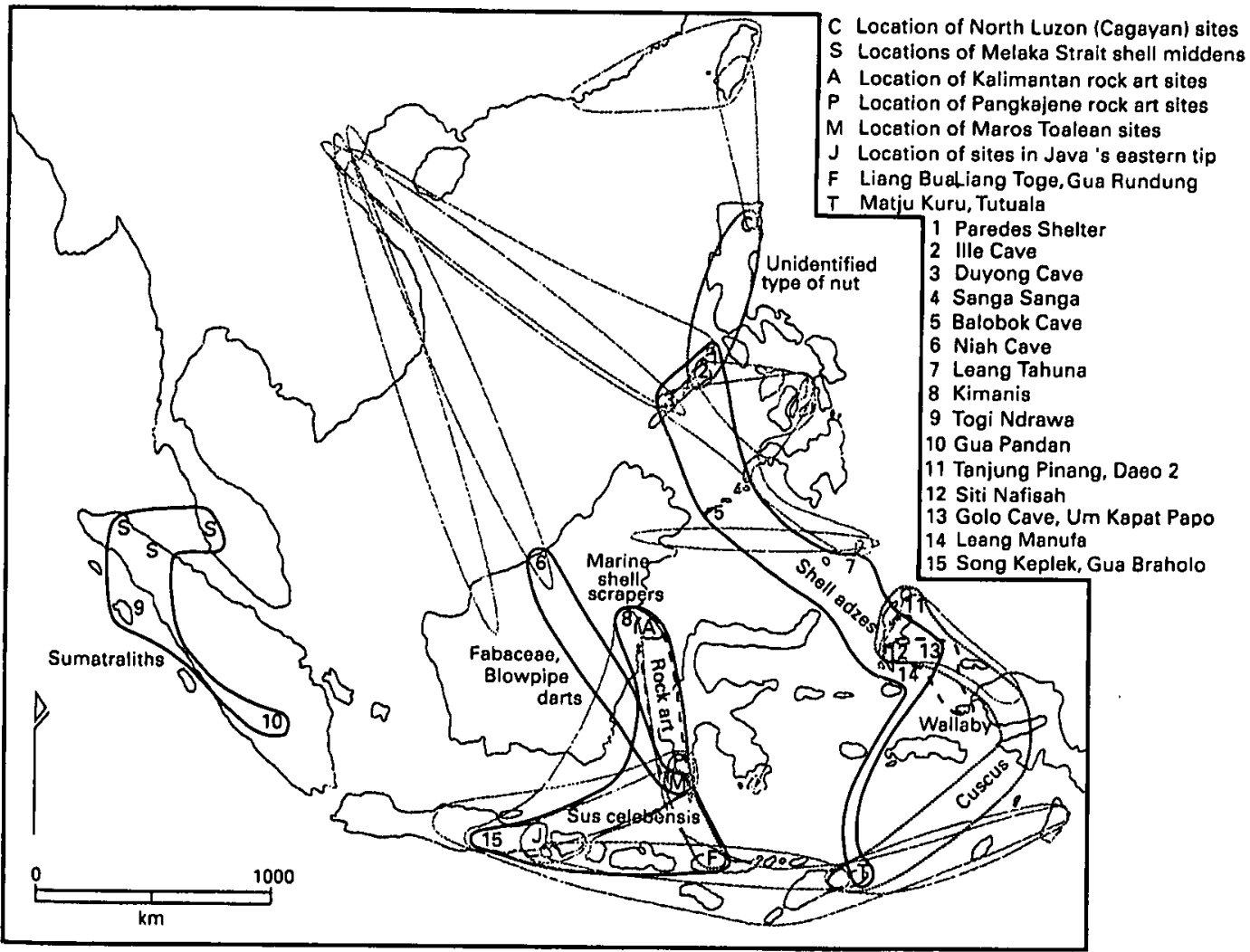

Figure 2 Early to mid-Holocene maritime interaction axes in ISEA and adjacent regions. 


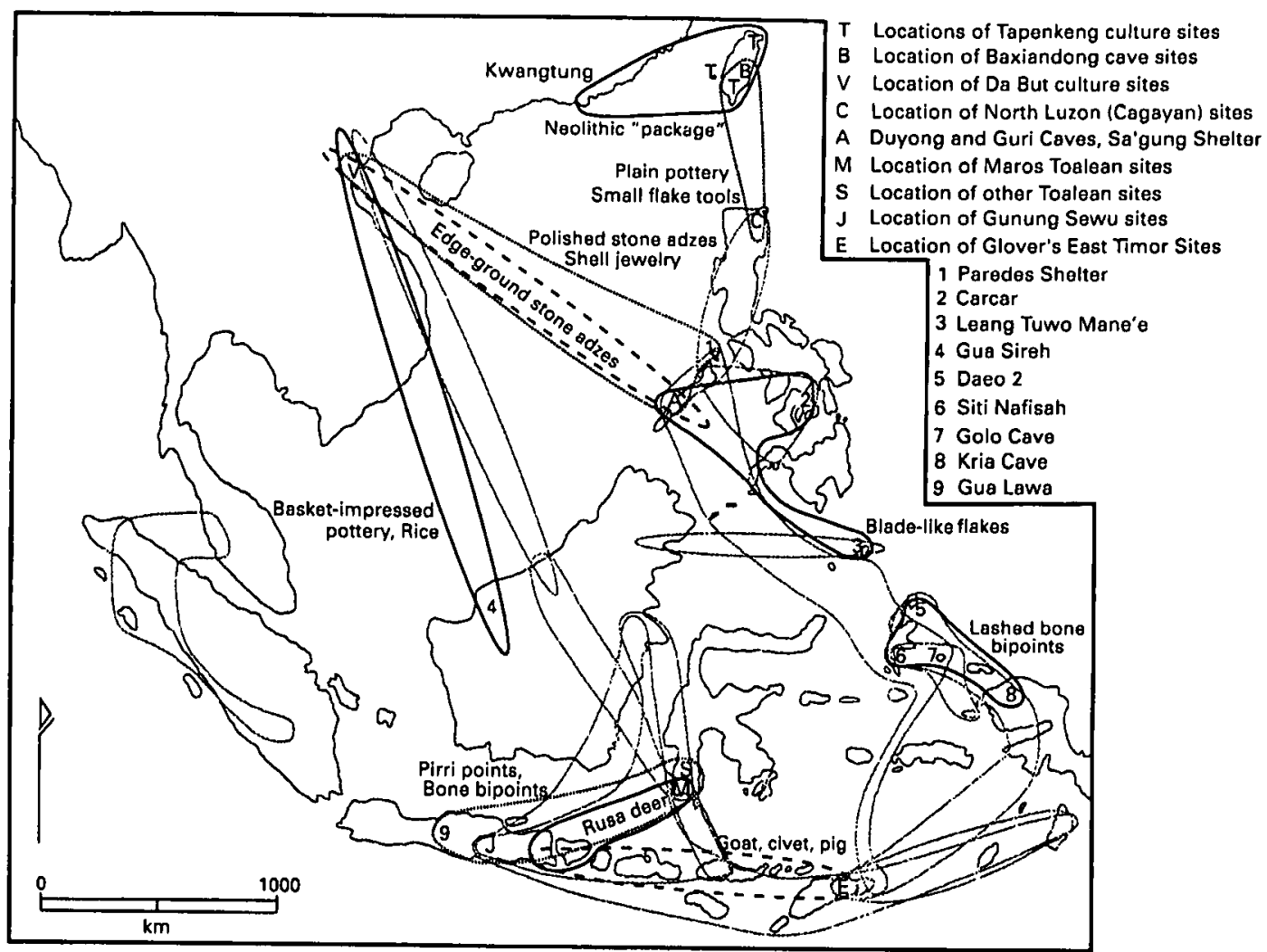

Figure 3 Specifically mid-Holocene maritime interaction axes in ISEA and adjacent regions.

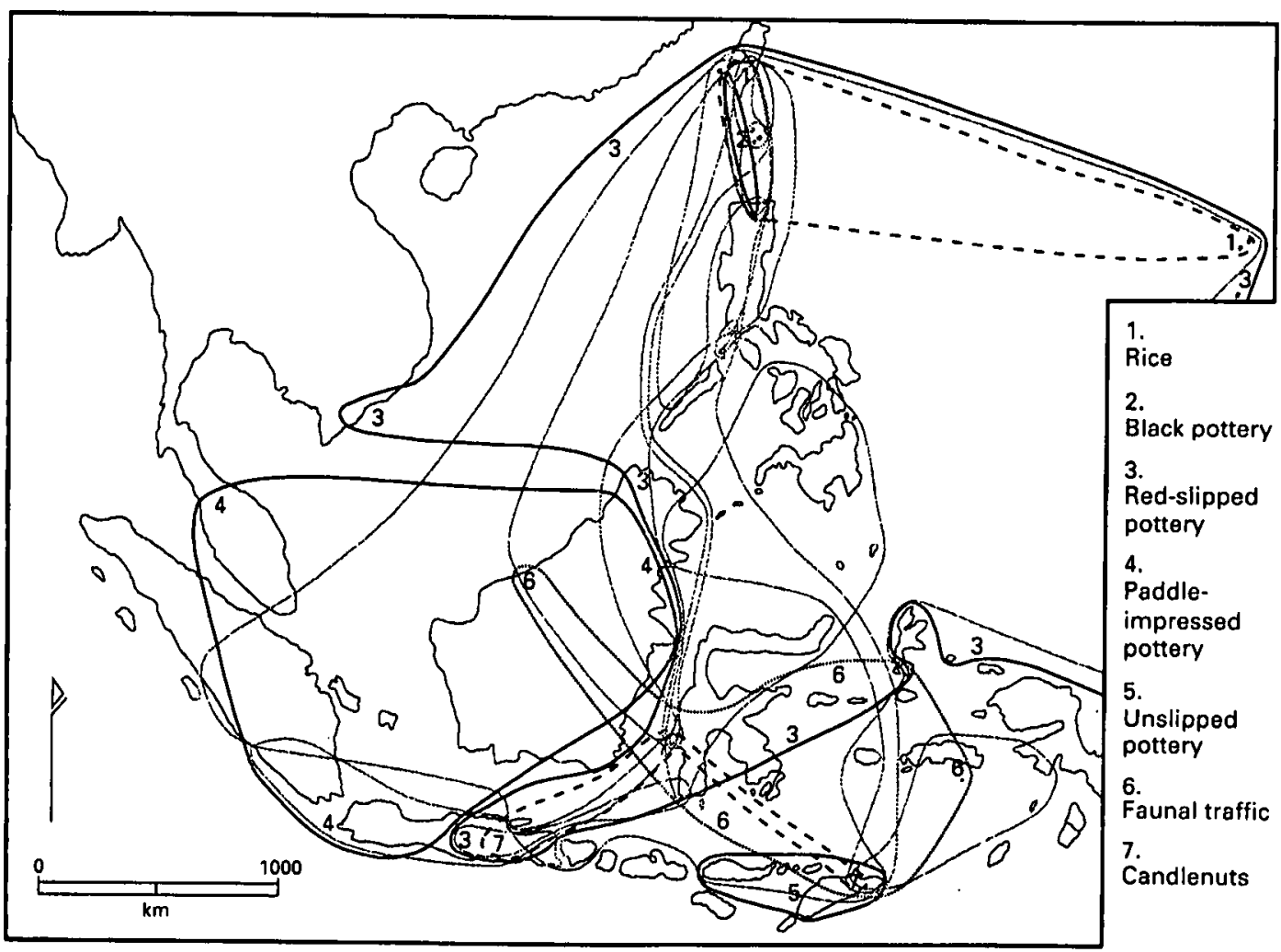

Figure 4 Distribution of pottery, economic plants and transported fauna across ISEA and adjacent regions 2500-4000 BP. 


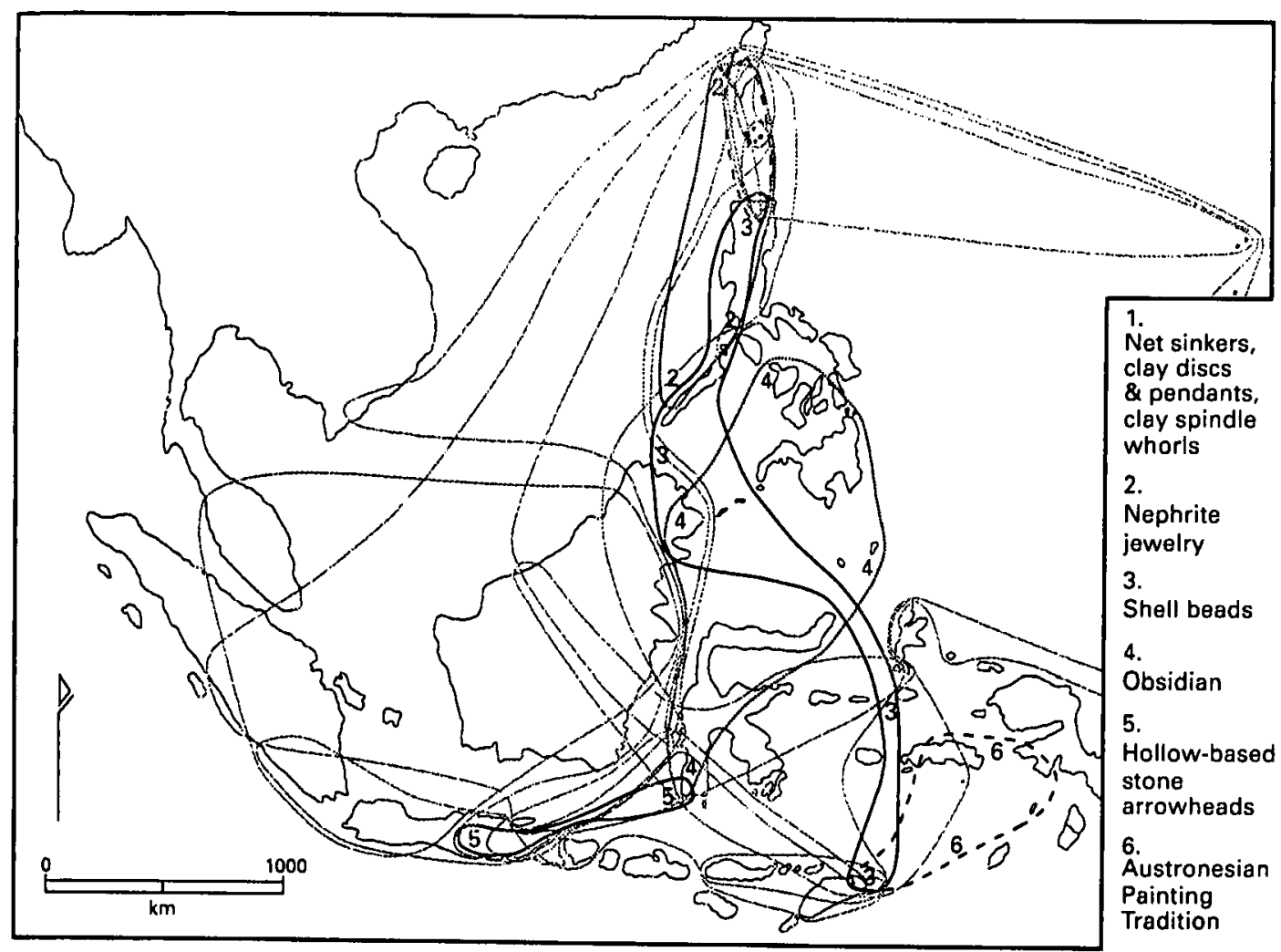

Figure 5 Distribution of miscellaneous items associated with the Neolithic across ISEA and adjacent regions.

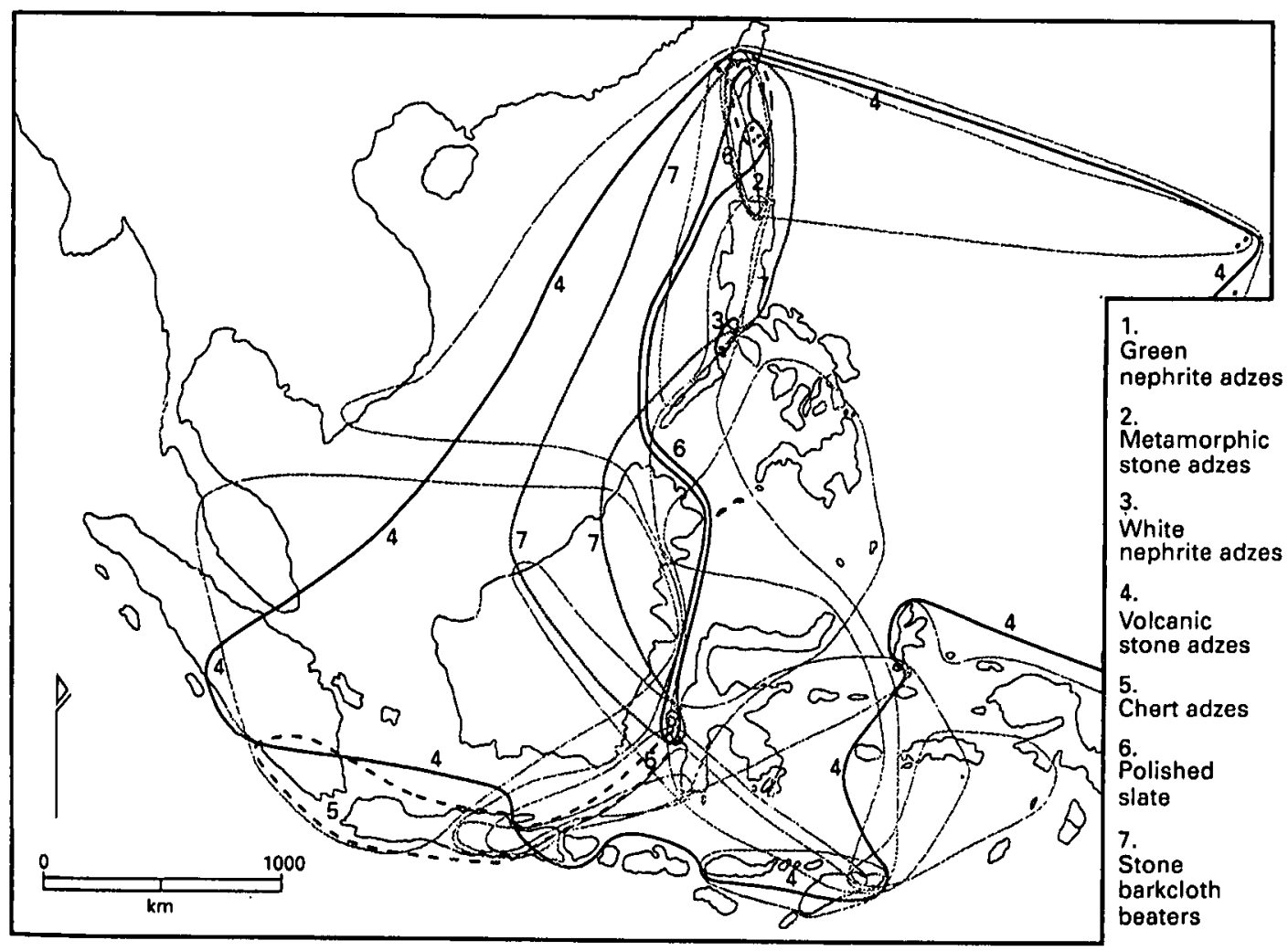

Figure 6 Distribution of polished stone tools across ISEA and adjacent regions 2500-4000 BP. 
between the Neolithic and the Early Metal Phase are a matter for future research.

\section{Discussion}

On the available archaeological and biological evidence, interpreting the linguistic evidence to infer an agriculturallyfuelled population expansion of early Austronesians into ISEA (Bellwood 1997; Diamond and Bellwood 2003; Howells 1973; Pawley 2002; Shutler and Marck 1975) is currently untenable. Yet the archaeological evidence certainly supports an origin of Austronesian in the Taiwan Strait, and subsequent dispersal of Malayo-Polynesians across ISEA. The advantage that evidently allowed this dispersal was an advanced maritime capacity, as would be logical for expansion across an island world. The benefits included superior exploitation of marine resources which abound in the region, and the traffic in useful technology, human experiences, and sumptuary goods across the Archipelago. Precursors of this maritime capacity are in evidence in ISEA before $4000 \mathrm{BP}$, and may have contributed to the geographical structure of the ISEA Neolithic maritime network, but the latter was clearly a quantum leap above previous developments. So pervasive was this Neolithic network, and so advantaged were those who operated it or at least connected to it, that, by ethnographic times, the vast majority of the languages of ISEA, whether spoken by 'Mongoloids' or 'Negritos', were Malayo-Polynesian.

I hope it is clear from my contribution that I heartily endorse a multidisciplinary approach to ISEA prehistory, and the 'triangulation' of the linguistic, archaeological and biological cvidence relevant to the Neolithic (e.g.Sagart et al.2005). However, I have little sympathy for taking a particular interpretation of the historical linguistics, one based on idealist culture history and the assumption of an expanding Malayo-Polynesian monoculture, and using it to overwrite the archaeological and biological evidence. In my view this reduces the number of disciplines that count to one, which is the opposite of multidisciplinary research. Although the link between Austronesian origins and a farming capacity in the region of the Taiwan Strait is clear, this is no reason to amplify this finding into an agricultural expansion of Malayo-Polynesians across ISEA, a proposition for which the evidence is sorely lacking. The biological evidence is our guide to the timing and extent of prehistoric population movement, while the archaeology is our handle on the material culture available at different places and the connections forged between prehistoric communities in the past. Multidisciplinary use of the historical linguistic evidence would accept the independently adduced biological and archaeological evidence, and interpret the wider implications of the historical linguistics accordingly.

A clear advantage of the multidisciplinary approach, and hence my contribution here, is the provision of maps detailing the relevant archacological evidence (Figures 1-6). Previous overviews (e.g. Bellwood 1997; Oppenheimer 1998; Solheim 2006) offer an anecdotal coverage of the archaeology, and provide maps primarily to depict site locations, putative homelands, and arrows representing hypothesised population movements. When we actually plot the archaeological evidence, we encounter partial justification for all the keynote views expressed on Austronesian origins, but full support for none of them. Additionally, the exercise I have undertaken has highlighted previously disregarded connections such as the strong and long-lived Java-Sulawesi axis. The methodology employed here, which takes an explicitly empirical approach to the archaeological evidence rather than force it into a preconceived scenario, is hardly the final word on the topic, but hopefully forges a step in the right direction.

\section{Conclusion}

Solheim (2006) and Oppenheimer and Richards (2002) appear to be justified in their argument that Austronesian foundations in ISEA are based on maritime trade and foraging. To the degree that agriculture played any significant role in early MalayoPolynesian dispersal, it would appear to have involved trees and tubers equally exploited in pre-Neolithic times. Bellwood (1997, 2005a) appears to be justified in his argument for Austronesian origins associated with cereal agriculture in southeast China and Taiwan. However, the linguistic expansion southwards did not involve the transplantation of this economy to ISEA, but instead enhanced the latent benefits of a maritime economy already in place.

\section{Acknowledgments}

My thanks to Stuart Bedford and two anonymous referces for their valuable comments on the originally submitted version of this manuscript.

\section{References}

Adelaar, K.A. 1995 Borneo as a cross-roads for comparative Austronesian linguistics. In P. Bellwood, J.J. Fox and D. Tryon (eds), The Austronesians: Comparative and Historical Perspectives, pp.75-95. Canberra: Australian National University.

Adi, H.T. 2000 Archaeological Excavations in Ulu Kelantan, Peninsular Malaysia. Unpublished PhD thesis, School of Archaeology and Anthropology, Australian National University, Canberra.

Anderson, A. 2005 Crossing the Luzon Strait: Archaeological chronology in the Batanes Islands, Philippines and the regional sequence of Neolithic dispersal. Journal of Austronesian Studies 1(2):25-44.

Arifin, K. 2004 Early Human Occupation of the East Kalimantan Rainforest (the Upper Birang River Region, Berau). Unpublished PhD thesis, School of Archacology and Anthropology, Australian National University, Canberra.

Bacus, E. 2004 A consideration of processes underlying Philippine pottery complexes. In V. Paz (ed.), Southeast Asian Archaeology: Wilhelm G. Solheim II Festschrift, pp.128-157. Diliman, Quezon City: University of Philippines Press.

Ballard, C. 1988 Dudumahan: A rock art site on Kai Kecil, S.E. Moluccas. Bulletin of the Indo-Pacific Prehistory Association 8:139-161.

Barker, G. 2005 The archaeology of foraging and farming at Niah Cave, Sarawak. Asian Perspectives 44:90-106

Bellwood, P. 1978 Man's Conquest of the Pacific. Sydney: Collins.

Bellwood, P. 1985 Prehistory of the Indo-Malaysian Archipelago. Sydney: Academic Press.

Bellwood, P. 1995 Archaeological research in the northern Moluccas 1991-1994 - A preliminary report. Southeast Asian Archaeology International Newsletter 7:3-12.

Bellwood, P. 1997 Prehistory of the Indo-Malaysian Archipelago. Honolulu: University of Hawai'i Press.

Bellwood, P. 1998 The archaeology of Papuan and Austronesian prehistory in the Northern Moluccas, eastern Indonesia. In R. Blench and M. Spriggs (eds), Archaeology and Language II: Correlating Archaeological and Linguistic Hypotheses, pp.J28-139. London: Routledge.

Bellwood, P. 2000 Some thoughts on understanding the human colonisation of the Pacific. People and Culture in Oceania 16:5-17. 
Bellwood, P. 2001 Taiwan. in P. Peregrine and M. Ember (eds), Encyclopedia of Prehistory: East Asia and Oceania, pp.299-301. Vol. 3. New York: Kluwer Academic/Plenum Publishers.

Bellwood, P. 2005a First Farmers: The Origins of Agricultural Societies. Oxford: Blackwell Publishing.

Bellwood, P. 2005b Coastal South China, Taiwan, and the prehistory of the Austronesians. In C-Y. Chiy and J-G. Pan (eds), The Archaeology of Southeast Coastal Islands of China Conference, pp.2-22. Taiwan: Executive Yuan Council for Cultural Affairs.

Bellwood, P. 2006 Borneo as the homeland of Malay? The perspective from archaeology. In J.T.Collins and Awang Sariayn (eds), Borneo and the Homeland of the Malays, pp.45-123. Kuala Lumpur: Bawan Bahasa dan Pustaka.

Bellwood, P. and J. Diamond 2005 On explicit 'replacement' models in Island Southeast Asia: A reply to Oppenheimer. World Archaeology 37:503-506.

Bellwood, P. and E. Dizon 2005 The Batanes Archaeological Project and the 'Out of Taiwan' hypothesis. Journal of Austronesian Studies I(1):1-33.

Bellwood, $P$, and P. Koon $1989^{\circ}$ 'Lapita colonists leave boats unburned!' The question of Lapita links with Island Southeast Asia. Antiquity 63:613-622.

Bellwood, P., R. Gillespie, G.B. Thompson, J.S. Vogel, I.W. Ardika and I. Datan 1992 New dates for prehistoric Asian rice. Asian Perspectives 31:161-170.

Bird, M.I., I.D. Taylor and C. Hunt 2005 Palaeoenvironments of insular Southeast Asia during the Last Glacial Period: A savannah corridor in Sundaland? Quaternary Science Review 24:2228-2242.

Blench, R. 2004 Fruits and arboriculture in the Indo-Pacific region. Bulletin of the Indo-Pacific Prehistory Association 24:31-50.

Blench, R. 2005 From the mountains to the valleys: Understanding ethnolinguistic geography in Southeast Asia. In L. Sagart, R. Blench and A. Sanchez-Mazas (eds), The Peopling of East Asia: Putting Together Archaeology, Linguistics and Genetics, pp.31-50. New York: Routledge.

Blust, R.A. 1976 Austronesian culture history: Some linguistic inferences and their relations to the archaeological record. World Archneology 8:19-43.

Blust, R. 1995 The prehistory of the Austronesian-speaking peoples: A view from language. Journal of World Prehistory 9:453-510.

Bowdler, S. 2002 Hunters and traders in northern Australia. In K.D. Morrison and L..L. Junker (eds), Forager-Traders in South and Southeast Asia: Long-Term Histories, pp. 167-184. Cambridge: Cambridge University Press.

Bower, N.W., Y. Yasumoto, M.F. Oxenham, L.C. Nguyen and K.T. Nguyen 2006 Preliminary reconstruction of diet at a Neolithic site in Vietnam using stable isotope and $\mathrm{Ba} / \mathrm{Sr}$ analyses. Bulletin of the Indo-Pacific Prehistory Association 26:79-85.

Bulbeck, D. 1999 Current biological anthropological research on Southeast Asia's Negritos. SPAFA Journal 9(2):14-22.

Bulbeck, D. 2003 Hunter-gatherer occupation of the Malay Peninsula from the Ice Age to the Iron Age. In J. Mercader (ed.), Under the Canopy, pp.119-160. New Brunswick: Rutgers University Press.

Bulbeck, D. 2004a Divided in space, united in time: The Holocene prehistory of South Sulawesi. in J.M. Pasveer and S. Keates (eds), Quaternary Research in Indonesia, pp.129-166. Leiden: A.A. Balkema.

Bulbeck, D. 2004b South Sulawesi in the corridor of populations along East Asia's Pacific rim. In I.M. Pasveer and S. Keates (eds), Quaternary Research in Indonesia, pp.221-258. Leiden: A.A. Balkema.

Bulbeck, D. 2005 Roonka and the Transition from Australoid to Australian Craniometrics. Paper presented at the 19 th Annual Conference of the Australasian Society for Human Biology, University of New South Wales, Sydney, Australia, 5-8 December 2005. Retrieved 2] September from http:// arts.anu.edu.au/bullda/roonka.html.

Bulbeck, D. $2008 \mathrm{An}$ archaeological perspective on the diversification of the languages of the South Sulawesi stock. In T. Simanjuntak (ed.), Austrmesian in Sulawesi, pp. 185-212. Jakarta: Center for Prehistoric and Austronesian Studies.
Bulbeck, D., M. Pasqua and A. Di Lello. 2000 Culture history of the Toalean. Asian Perspectives 39:71-108.

Bulbeck, F.D. and Nasruddin 2002 Recent insights on the chronology and ceramics of the Kalumpang site complex, South Sulawesi, Indonesia. Bulletin of the IndoPacific Prehistory Association 22:83-99

Chazine, J-M. 2004 Rock art from Borneo: A comparative approach. In XXI Valcamonica Symposium, Art Prehistorica e Tribale, 8 - 14 Settembre 2004, Palazzo dei Congressi - Darfo Boario Terme, Papers, pp.164-172. Capo di Ponte: Edizione del Centro Camuno di Studi Preistorica.

Chazine, J-M. 2005 Rock art, burials, and habitations: Caves in East Kalimantan. Asian Perspectives 44:219-230.

Chen, J.C-Y. 2002 Sea nomads in prehistory on the southeast coast of China. Bulletin of the Indo-Pacific Prehistory Association 22:51-54.

Clark, G.R. 2005 A 3000-year culture sequence for Palau, western Micronesia. Asian Perspectives 44:339-380.

Datan, I. 1990 Archacological Excavations at Gua Sireh (Serian) and Lubang Angin (Gunung Mulu National Park),Sarawak,Malaysia.Unpublished MA thesis,School of Archaeology and Anthropology, Australian National University, Canberra.

Diamond, l. and P. Bellwood 2003 Farmers and their languages: The first expansions. Science 300:597-603.

Fage, L-H. 2005 Hands across time. National Geographic 208(2):32-45.

Flannery, T.F., P. Bellwood, J.P. White, T. Ennis, G. Irwin, K. Schubert and S. Balasubramaniam 1998 Mammals from Holocene archaeological deposits on Gebe and Morotai islands, Northern Moluccas, Indonesia. Australian Mammalogy 20:391-400.

Forestier, H. 2007 Ribuan Gunung, Ribuan Alat Batu: Prasejarah Song Keplek, Gunung Sewu, Jawa Timur. Jakarta: Kepustakaan Populer Gramedia.

Forestier, H., T. Simanjuntak, D. Guillard, D. Driwantoro, K. Wiradnyana, D. Siregar, D.A. Rokus and Budiman 2005 Le site de Togi Ndrawa, ile de Nias, Sumatra nord: Les premières traces d'une occupation hoabinhienne en grotte en Indonésie. Comptes Rendus Palevol 4:727-733.

Forestier, H., D. Driwantoro, D. Guillaud, Budiman and D. Siregar 2006 New data for the prehistoric chronology of South Sumatra. In T. Simanjuntak, M. Hisyam, B. Prasetyo and Titi Surti Nastiti (eds), Archaeology: Indonesian Perspective: R.P. Soejono's Festschrift, pp.177-192. Jakarta: Indonesian Institute of Sciences (LIPI).

Fox, R. 1970 The Tabon Caves. Manila: National Museum.

Glover, I.C. 1985 Some problems relating to the evidence of rice in Asia. In V. Misra and P. Bellwood (eds), Recent Advances in Indo-Pacific Prehistory, pp.265-274. Leiden: E.J. Brill.

Glover, I.C. 1986 Archaeology in Eastern Timor. Canberra: Australian National University.

Glover, I.C. and G. Presland 1985 Microliths in Indonesian fiaked stone industries. In V. Misra and P. Bellwood (eds), Recent Advances in Indo-Pacific Prehistory, Pp. 185-195. Leiden: E.J. Brill.

Guillard,D.,H.Forestier,A. Romsan and B. Prasetyo 2006 Bab 2: Daerah pegungungan: Sebuah pendekatan arkeogeografis untuk mengetengahkan zaman protosejarah. In D. Guillard (ed.), Menyelusuri Sungai, Merunut Waktu: Penelitian Arkeologi di Sumatera Selatan, pp.35-47. Jakarta: PT Enrique Indonesia.

Higham, C. 2002 Early Cultures of Mainland Southeast Asia. Bangkok: River Books.

Hill, C., P. Soares, M. Mormina, V. Macaulay, W. Meehan, J. Blackburn, D. Clarke, J.M. Raja, P. Ismail, D. Bulbeck, S. Oppenheimer and M. Richards 2006 Phylogeography and ethnogenesis of aboriginal Southeast Asians. Molecular Biology and Evolution 23:2480-2491.

Hill, C., P. Soares, M. Mormina, V. Macaulay, D. Clarke, P.B. Blumbach, M. VizueteForster, P. Forster, D. Bulbeck, S. Oppenheimer and M. Richards 2007 A mitochondrial stratigraphy for Island Southeast Asia. The American Journal of Human Genetics 80:29-43. 
Howells, W. 1973 The Pacific Islanders. London: Weidenfeid and Nicolson.

Hung, H-C. 2004 A sourcing study of Taiwan stone adzes. Bulletin of the IndoPacific Prehistory Association 24:57-70.

Hung, H-C. 2005 Neolithic interaction between 'Taiwan and northern Luzon: The pottery and jade evidences from the Cagayan Valley. Journal of Austronesian Studies 1(1):109-133.

Hung, H-C., Y. lizuka, P. Bellwood, K.D. Nguyen, B. Bellina, P. Silapanth, E. Dizon, R. Santiago, I. Datan and J.H. Manton 2007 Ancient jades map 3,000 years of prehistoric exchange in Southeast Asia. Proceedings of the National Academy of Sciences of the United States of America 104(50):19745-19750.

lizuka, Y. and H.C. Hung 2005 Archaeomineralogy of Taiwan nephrite: Sourcing studies of nephritic artifacts from the Philippines. Journal of Austronesian Studies I(1):35-81.

Jett, S.C. 1970 The development and distribution of the blowgun. Annals of the Association of American Geographers 60:662-688.

Kress, J. 2004 The necrology of Sa'gung rockshelter and its place in Philippine prehistory, In V. Paz (ed.), Southeast Asian Archaeology: Wilhelm G. Solheim II Festschrift, pp.239-75. Diliman, Quezon City: University of Philippines Press.

Krigbaum, J. and J. Manser 2005 The West Mouth burial series from Niah Cave: Past and present. In M. Zuraina (ed.), The Perak Man and other Prehistoric Skeletons of Malaysia, pp. 175-206. Penang: Penerbit Universiti Sains Malaysia.

Mahirta 2003 Human Occupation on Rote and Sawu Islands, Nusa Tenggara Timur. Unpublished PhD thesis, School of Archacology and Anthropology, Australian National University, Canberra.

Manser, J. 2005 Morphological Analysis of the Hurnan Burial Series at Niah Cave: Implications for Late Pleistocene-Holocene Southeast Asian Human Evolution (Indonesia). Unpublished PhD thesis, New York University, New York.

Matsumura, H. and M. Hudson 2005 Dental perspectives on the population history of Southeast Asia. American Journal of Physical Anthropology 127:182-209.

Meacham, D. 1984-1985 On the improbability of Austronesian origins in South China. Asian Perspectives 26:89-106.

Meacham, D. 2004 Solheim and Austronesian origins. In V. Paz (ed.), Southeast Asian Archaeology: Wilhelm G. Solheim II Festschrift, pp.53-63. Diliman, Quezon Ciry: University of Philippines Press.

Mijares, A.S.B. 2007 Unearthing Prehistory: The Archaeology of Northeastern Luzon, Philippine Islands. BAR International Series 1613. Oxford: British Archaeological Reports.

Morwood, M and P. van Osterzee 2007 The Discovery of the Hobbit. Sydney: Random House.

Neri, L.A.M. 2007 Philippine obsidian and its archaeological applications. Bulletin of the Indo-Pacific Prehistory Association 27:154-162.

Nguyen V. 2005 The Da But culture: Evidence for cultural development in Vietnam during the middle Holocene. Bulletin of the Indo-Pacific Prehistory Association 25:89-94.

O'Connor, S. 2006 Unpacking the Island Southeast Asian Neolithic cultural package, and finding local complexity. In E.A. Bacus, I.C. Glover and V.C. Pigott (eds), Uncovering Southeast Asia's Past, pp.74-86. Singapore: National University of Singapore Press.

O'Connor, S. 2007 New evidence from East Timor contributes to our understanding of earliest modern human colonisation east of the Sunda Shelf. Antiguity 81:523-535.

$O^{\prime}$ Connor, S. and N. Vasco Oliverra. 2007 Inter- and intraregional variation in the Austronesian Painting Tradition: A view from East Timor. Asian Perspectives 46:389.403.

O'Connor, S., K. Aplin, J. Pasveer and G. Hope 2005a Liang Nabulei Lisa: A late Pleistocene and Holocene sequence from the Aru Islands. In S. O'Connor, M. Spriggs and P. Veth (eds), The Archaeology of the Aru Islands, Eastern Indonesia, pp.125-161. Terra Australis 22. Canberra: Pandanus Press.
O'Connor, S., K. Aplin, K. Szab6, J. Pasveer, P. Veth and M. Spriggs 2005b Liang Lemdubu: A Pleistocene cave site in the Aru Islands. In S. O'Connor, M.Spriggs and P. Veth (eds), The Archaeology of the Aru Islands, Eastern Indonesia, pp. 171-204. Terra Australis 22. Canberra: Pandanus Press.

Olsen, S.L and I.C. Glover 2004 The bone industry of Ulu Leang 1 and Leang Burung I rockshelters, Sulawesi, Indonesia, in its regional context. In J.M Pasveer and S. Keates (eds), Quaternary Research in Indonesia, pp.273-299. Leiden: A.A. Balkema.

Ono, R. 2003 Prehistoric Austronesian fishing strategies: A comparison between Island Southeast Asia and the Lapita Cultural Complex. In C. Sand (ed.), Pacific Archaeology: Assessments and Prospects, pp.191-201. Noumea: Le Cahiers de l'Archéologie en Nouvelle-Calédonie 15.

Ono, R. 2004 Prehistoric fishing at Bukit Tengkorak, east coast of Borneo Island. New Zealand Journal of Archaeology 24:77-106.

Oppenheimer, S. 1998 Eden in the East: The Drowned Continent of Sundaland. London: Pheonix.

Oppenheimer, S. 2004a Out of Eden: The Peopling of the World. London: Robinson.

Oppenheimer, S. 2004b The 'Express train from Taiwan to Polynesia' on the congruence of proxy lines of evidence. World Archaeology 36:591-600.

Oppenheimer, S. and M. Richards 2002 Polynesians: Devolved Taiwanese rice farmers or Wallacean maritime traders with fishing, foraging and horticultural skills? In P. Bellwood and C. Renfrew (eds), Examining the Farming/Language Dispersal Hypothesis, pp.287-297. Cambridge: McDonald Institute for Archaeological Research, Cambridge University.

Pasveer, J.2005 Bone artefacts from Liang Lemdubu and Liang Nabulei Lisa, Aru Islands. In S. O'Connor, M. Spriggs and P. Veth (eds), The Archaeology of the Aru Islands, Eastern Indonesia, pp.235-254. Terra Australis 22. Canberra: Pandanus Books.

Pasveer, J.M. and P. Bellwood 2004 Prehistoric bone artefacts from the northern Moluccas, Indonesia. In J.M. Pasveer and S. Keates (eds), Quaternary Research in Indonesia, pp. 301-360. Leiden: A.A. Balkema.

Pawley, A. 2002 The Austronesian dispersal: Languages, technologies and people. In P. Bellwood and C. Renfrew (eds), Examining the Farming/Language Dispersal Hypothesis, pp.251-273. Cambridge: McDonald Institute for Archaeological Research, Cambridge University.

Pawley, A. and R. Green 1973 Dating the dispersal of the Oceanic languages. Oceanic Linguistics 12:1-67.

Paz, V. 2002 Island Southeast Asia: Spread or fiction zone? In P. Bellwood and C. Renfrew (eds), Examining the Farming/Language Dispersal Hypothesis, pp. 275 285. Cambridge: McDonald Institute for Archaeological Research, Cambridge University.

Paz, V.J. 2004 Of nuts, seeds and tubers, archaeobotanical evidence from Leang Burung 1. In J.M. Pasveer and S. Keates (eds), Quaternary Research in Indonesia, pp.193-219. Leiden: A.A. Balkema.

$\mathrm{Paz}, \mathrm{V} .2005$ Rock shelters, caves, and archaeobotany in Island Southeast Asia. Asian Perspectives 44:107-118.

Pyatt, E.B., B. Wilson and G.W. Barker 2005 The chemistry of tree resins and ancient rock paintings in the Niah Caves, Sarawak (Borneo). Journal of Archaeological Science 32:897-901.

Prasetyo, B. 2002 The bone industry. In T. Simanjuntak (ed.), Gunung Sewu in Prehistoric Times, pp.181-194. Yogyakarta: Gadjah Mada Press.

Rabett, R.J. 2005 The early exploitation of Southeast Asian mangroves: Bone technology from caves and open sites. Asian Perspectives 44:154-179.

Rolett, B.V., T. Jiao and G. Lin 2002 Early seafaring in the Taiwan Strait and the search for Austronesian origins. Journal of East Asian Archaeology 4:307-319.

Sagart, L. 2005 Sino-Tibetan-Austronesian: An updated and improved argument. In L.Sagart, R. Blench and A. Sanchez-Mazas (eds), The Peopling of East Asia: Putting Together Archaeology, Linguistics and Genetics, pp. 161-176. New York: Routledge. 
Sagart, L., R. Blench and A. Sanchez-Mazas 2005 Introduction. In L. Sagart, R. Blench and A. Sanchez-Mazas (eds), The Peopling of East Asia: Putring Together Archaeology, Linguistics and Genetics, pp. 1-14. New York: Routledge.

Shutler, R. and J.C. Marck 1975 On the dispersal of the Austronesian horticulturalists. Archaeology and Physical Anthropology in Oceania 10:81-113.

Simanjuntak, T. and B. Prasetyo 2002 The Neolithic of Gunung Sewu: From caves to open sites. In T. Simanjuntak (ed.), Gunung Sewu in Prehistoric Times, pp.206211. Yogyakarta: Gadjah Mada Press.

Simanjuntak, T., H. Forestier, D. Driwantoro, Jatmiko and D. Sinegar 2006 Bab 1 - Daerah kaki gunung: Berbagai tahap zaman batu. In D. Guillaud (ed.), Menyulusir Sungai, Merunut Waktu: Penelitian Arkeologi di Sumatera Selatan, pp.21-33. Jakarta: PT Enrique Indonesia.

Simanjuntak, T., M.J. Morwood, F.S. Intan, I. Mahmud, K. Grant, N. Somba Bernadeta AKW and D.W. Utomo 2008 Minanga Sipakko and the Neolithic of the Karama River. In T. Simanjuntak (ed.), Austronesian in Sulawesi, pp.57-75. Jakarta: Center for Prehistoric and Austronesian Studies.

Simons, A. and D. Bulbeck 2004 Late Quaternary faunal successions in South Sulawesi, Indonesia. In J.M. Pasveer and S. Keates (eds), Quaternary Research in Indonesia, pp.167-189. Leiden: A.A. Balkema.

Soares, P., J.A. Trejaut, J-H. Loo, C. Hill, M. Mormina, C.-L. Lee, Y.-M. Chen, G. Hudjashov, P. Forster, V. Macaulay, D. Bulbeck, S. Oppenheimer, M. Lin and M. Richards 2008 Climate change and postglacial human dispersals in Southeast Asia. Molecular Biology and Evolution 25(6):1209-1218.

Soegondho, S. 1995 Earthenware Traditions in Indonesia from Prehistory until the Present. Jakarta: Himpunan Keramik Indonesia.

Soejono, R.P. 1985 Laporan Penelitian Arkeologi di Liang Bua. Jakarta: LPA Bidang Preasejarah Puslitarkenas.

Solheim, W.G. II. 1975 The Nusantao and South China. Journal of the Hong Kong Archaeological Society 6:108-115.

Solheim, W.G. II. 1984-85 The Nusantao hypothesis: The origin and spread of Austronesian speakers. Asian Perspectives 26:77-88.

Solheim, W.G. II. 2006 Archaeology and Culture in Southeast Asia: Unraveling the Nusantao. Diliman, Quezon City: University of Philippines Press.

Solheim, W.G. II, A.M. Legaspi and S.J. Neri 1979 Archaeological Survey in Southeastern Mindanao. Monograph 8. Manila: National Museum of the Philippines.

Spriggs, M. 1989 Dating the Island Southeast Asian Neolithic. Antiquity 63:587. 612.

Spriggs, M. 2003 Chronology of the Neolithic transition in Island Southeast Asia and the Western Pacific: A vicw from 2003. The Review of Archaeology 24(2):57-80.
Spriggs, M. 2007 The Neoiithic and Austronesian expansion within Southeast Asia and into the Pacific. In S. Chiu and C. Sand (eds), From Southeast Asia to the Pacific: Archaeological Perspectives on the Austronesian Expansion and the Lapita Cultural Complex, pp.104-140. Taipei: Academica Sinica.

Storm, P. 1995 The Evolutionary Significance of the Wajak Skuils. Scripta Geologica 110. Leiden: National Natuurhistorisch Museum.

Sumantri, I. 1996 Pola Pemukiman Gua-Gua Prasejarah di Biracng Pangkep, Sulawesi Selatan. Unpublished MA thesis, Archaeology Studies Programme University of Indonesia, Jakarta.

Szabó, K. and S. O'Connor 2004 Migration and complexity in Holocene Island Southeast Asia. World Archaeology 36:621-628.

Tanudirjo, D. 2001 Islands in Between: Prehistory of the Northeastern Indonesian Archipelago. Unpublished PhD thesis, School of Archaeology and Anthropology Australian National University, Canberra.

Tsang C-H. 2000. Recent advances in the Iron Age archaeology of Taiwan. Bulletin of the Indo-Pacific Prehistory Association 20:153-158.

Tsang C-H. 2005 Recent discoveries at the Tapenkeng culture sites in Taiwan: Implications for the problem of Austronesian origins. In L Sagart, R. Blench and A. Sanchez-Mazas (eds), The Peopling of East Asia: Putting Together Archaeology, Linguistics and Genetics, pp.63-73. New York: RoutledgeCurzon.

Tsang C-H. 2007 Recent archaeological discoveries in Taiwan and northern Luzon. In S.Chiu and C. Sand (eds), From Southeast Asia to the Pacific: Archaeological Perspectives on the Austronesian Expansion and the Lapita Cultural Complex, pp.75-103. Taipei: Academica Sinica.

Tykot, R.H. and S. Chia 1997 Long-distance obsidian trade in Indonesia. In P.B. Vandiver, J.R. Druzik, I. Merkel and J. Stewart (eds), Theory in Archaeological Obsidian Studies, pp.67-82. New York: Plenum.

van Heekeren, H.R. 1972 The Stone Age of Indonesia. 2nd ed. The Hague: Martinus Nijhoff.

Veth, P., M. Spriggs and S. $0^{\prime}$ Connor 2005 Continuity in tropical cave usc: Examples from East Timor and the Aru Islands. Asian Perspectives 44:180-192.

Vita 2008 New insight on the paleovegetation of the Minanga Sipakko site. In T. Simanjuntak (ed.), Austronesian in Sulawesi, pp.93-104. Jakarta: Center for Austronesian and Prehistoric Studies.

Widianto, H. 2002. Prehistoric inhabitants of Gunung Sewu. In T. Simanjuntak (ed.), Gunung Sewu in Prehistoric Times, pp.227-248. Yogyakarta: Gadjah Mada Press.

Zhang S. 2000 The Epipalaeolithic in China. Journal of East Asian Archaeology 2:51-66. 